\title{
THE RISE OF THE CHINGGISID DYNASTY: PRE-MODERN EURASIAN POLITICAL ORDER AND CULTURE AT A GLANCE
}

\section{Lhamsuren Munkh-Erdene}

National University of Mongolia

E-mail Imunkherdene@yahoo.com

Analyzing the messages and the responses that Chinggis Khan sent to and received from Ong Khan and his allies after his defeat at the hands of the latter at the battle of Qalaqaljit Elet in the spring of I203, and explicating the terms of cimar (chimar) and törü that appear in the messages, this article looks at the political order and culture where the Chinggisid state rose. The article argues that pre-modern Mongolian and Inner Asian politics was guided by the idea of törü, which resembles the Indo-Buddhist idea of dharma, the Chinese idea of dao, and the European idea of natural law. It also argues that the hereditary divisional system that the Inner Asian state builders regularly employed to govern their nomadic populations, the institutions of dynastic succession, and the hereditary rights of princes and the nobility for inheritance fundamentally structured Inner Asian politics. Hence, it questions the conventional wisdom that depicts pre-modern Inner Asian politics not only as pragmatic, fluid, and fractious but also dependent on the personal charisma of leadership, and the personal bond and loyalty between leaders and followers, as if it were lacking enduring social, political institutions and order.

Keywords: Mongol Empire; Inner Asia; törü; chimar, moral regime; tradition; legitimacy; sovereignty

\section{THE DEBATE}

While the conventional scholarship maintains that the Chinggisid state was born to what was otherwise a tribal order of egalitarian kinship society that dominated pre-modern Inner Asia, recent revisionist scholarship claims that it was instead a perennial headless order of a myriad aristocratic houses whose whim and caprice, at times, gave way to a centralized state like that of the Chinggisid. ${ }^{\mathrm{I}}$

Lhamsuren Munkh-Erdene is currently a Humboldt Research Fellow at the Max Planck Institute for Social Anthropology. The author owes a debt of gratitude to the Humboldt Foundation for its generous support and is grateful to the editors and the anonymous reviewers of the International Journal of Asian Studies for their helpful comments.

I See Amitai and Biran 20I5; Di Cosmo, Frank and Golden 2009; Kradin and Skrynnikova 2009; Barfield I989, pp. 24-28; Sneath 2007. As Peter Golden (Golden 2009, p. I09) succinctly puts it, "In Inner Asia, the nomads were organized hierarchically in lineages, clans and tribes defined by descent, real or fictive, from a common 
Both before and after David Sneath, meantime, Christopher Atwood and myself have repeatedly demonstrated the untenability of the conventional reading not only of the premodern Mongolian terms oboq, and oboqtan, ${ }^{2}$ ayimaq, ${ }^{3}$ ulus, irgen, tümen, mingqan, otog, khoshuu, ${ }^{4}$ and qari, ${ }^{5}$ but also Chinese bu 部, buluo 部落, and buzu 部族. ${ }^{6}$ Needless to say, the relevant scholars concur in confirming Sneath in his critique of conventional scholarship's representation of Inner Asia as a pre-state kinship society. Furthermore, in order to persuade its readers, the conventional school, at least on a theoretical level, has to explain how swarming heterogeneous groups of free and fierce, egalitarian tribesmen sundered into a myriad conical clans divided in segmentary lineages with constant frictions and fissures, and yet scattered over an area as big as the country of Mongolia or the whole of Inner Asia, could command an all-embracing "topology", "synoptic view", or "seeing like a state vision" that made it possible for all those clans and tribes to form a single political entity.7

On the other hand, Sneath has to explain to us where his aristocratic houses came from, how they were made aristocratic, and how they figured out that they could form a single state. ${ }^{8}$ Also, his 1640 headless state is overly complicated on several counts. First, Hong Taiji had already been enthroned by the southern Mongolian princes as a successor to the Mongol Great Khan in 1636, and he was now claiming sovereignty over the rest of the Mongols. ${ }^{9}$ Thus, it is not that there was no monarch claiming sovereignty over the Mongols, but rather that there was a monarch who was not in a position to impose his sovereignty. Second, the I640 Great Code was not the creation of a headless state; on the contrary, it was a dismantlement of the Northern Yuan or Dayan Khanid Mongolia, a political order closely akin to that of the Holy Roman Empire and, as such, the I640 Great Code resembles the I648 Treaty of Westphalia. Furthermore, it emerged only in the intervening period after the demise of the Mongol Great Khan Ligdan in I634, when the succeeding Manchu Bogd Khan was unable to impose his sovereignty and his Mongol rival, the Zasagtu Khan Subudai, failed to enthrone himself as the next Mongol Great Khan. ${ }^{\text {Io }}$ Thus, the order established by the I640 Great Code was the exception rather than the norm in Inner Asia.

Meanwhile, Atwood and myself have advanced our own theoretical explanations of the pre-modern Mongolian and Eurasian socio-political order. Atwood, adopting a sort of

patrilineal ancestor .... Expanding clans could become tribe-like in power and authority. Tribes often formed loose, polyethnic unions, potential states depending on their response to interaction with neighbouring sedentary states." This reflects the typical conventional wisdom of the Inner Asian political order.

2 Atwood 20Iob, 2012, 2015, Munkh-Erdene 2006.

3 Atwood 20Iob, 2012, 20I5, Munkh-Erdene 20I0.

4 Atwood 2006, 20I0b, 20I2, 2015; Munkh-Erdene 2006, 20I0, 20II, 2016.

5 Atwood 2010b, 2015.

6 Atwood 20roa. Isenbike Togan's examination of Chinese terms of bu and buluo of Turkic period seems to reveal no tribal or kinship meaning, though she claims that "Sneath's hypothesis ... cannot be substantiated by the historical record"; Togan 2015, p. 89.

7 For the topological view see Foucault I994, and for the synoptic view or seeing-like-state vision Scott I998.

8 Sneath 2007.

9 Munkh-Erdene 2010.

Io Ibid. 
bottom-up ethnographic perspective and societal language, and covering Chinggisid (I 225I345)-, Dayan Khanid (I5IO-I625)-, and Qing (I645-I900)-era Mongolia, argues that the basic unit of traditional Mongolian society was "appanage communities" or "territorial divisions" - "a unit of local government" and "a closed, corporate community" - "deeply dependent on the state for their effective functioning". ${ }^{\text {I }}$ What emerges here is, of course, a fully state-organized society. In fact, these periods are largely accepted as the "state" periods of Mongolia or the Mongols. Thus, a conventional critic can object that Atwood's argument is built on Mongolia's less "tribal” or less problematic periods.

I myself, on the other hand, have adopted a top-down perspective and political language, covering the Liao, the Chinggisid, and the Qing successive incorporations of Inner Asia, and have argued that "the hereditary divisional system that these Inner Asian states employed to incorporate and administer their nomadic population was the engine that generated what scholars see either as 'tribal' or 'aristocratic order". "This divisional system, because of its hereditary membership and rulership, invariably tended to produce autonomous lordships with distinct names and identities unless central government took measures to curb the tendency. Whenever the central power waned, these divisions emerged as independent powers in themselves and their lords as contenders for the central power". ${ }^{\text {I2 }}$ Thus, the hereditary divisions - administrative divisions and lordly polities - were creations of imperial incorporations and administrations, that is, products of statecraft.

Each succeeding instance of imperial statecraft, in creating its own politico-administrative divisions, dismantled the emergent lordships or erstwhile administrative divisions, transforming them into quasi-political identity categories. Thus, my explanation not only looks at the "state" or "centralized state" periods and the problematic "tribal" or "headless aristocratic" periods, that is, pre-Chinggisid, and pre-Qing Mongolia, but also looks more precisely "at the origin or genesis of the named categories". The framework shows not only the origin of "tribes or aristocracy led named groups" but also the aristocratic houses themselves, and locates their origins in the houses of the hereditary commanders of the divisions. This explanation accounts for the victims of the state incorporation as well, that is, the quasipolitical identity categories, and the dismantled and disbanded divisional lordships. ${ }^{\mathrm{I}} 3$ Though the scheme does not pretend to explain every single case, it is claimed to be valid in many of the historical cases found in post-Xiongnu Eurasia. It is, then, a historicopolitical explanatory framework, for it is built on concrete historical examples and takes into account the innate logic of pursuit of power, rulership, governance, and administration, that is, statecraft and state building. The merits and demerits of this framework have yet to be appraised.

The conventional scholarship's tribal paradigm to explain the pre-modern Inner Asian political order has thus been increasingly challenged. Yet, its sway over pre-modern Inner Asian political culture has rarely been questioned. While many authors, including Peter Golden and Nicola di Cosmo, emphasize the continuity of the Inner Asian imperial

\footnotetext{
I I Atwood 20I2, pp. I-2.

I2 Munkh-Erdene 20I6, p. 633.

I3 Golden 2009 precisely depicts these processes, though unfortunately using tribal language.
} 
political traditions including the decimal system, ${ }^{\mathrm{I}}$ many of these same authors depict premodern Eurasian politics as being pragmatic, notoriously fragile, fluid, unstable, fractious, or even chaotic, defined by swarming tribes and clans. "In the nomadic society of northern Asia such political groupings were always highly fluid, with many small and intricately interrelated tribal groups that would join together in military confederations in times of crisis. These confederations were always very unstable, and dependent above all on the personal charisma of their leaders and, after a short period of common purpose and unity under strong leadership, would inevitably split again" is the conventional depiction of premodern Inner Asian politics. ${ }^{15}$

Irrational-sounding features such as the notion of the divine mandate of a shamanic deity and personal charisma, and tribal-sounding features such as kinship and consanguinity, personal bond and loyalty, free and fierce, and barbarian and savage are the oftenhighlighted features of pre-modern Eurasian politics. For instance, in The Cambridge History of Inner Asia, The Chinggisid Age, we read lines such as "Steppe politics were notoriously fragile”, "fractious”, “... along traditional Inner Asian lines, ... military aristocracy established a personal bond of allegiance to the Qaghan", or "personal bond between the chieftain and his nökürs was the bedrock of political loyalty", or "all-important personal bonds between ruler and servitor", or "charisma", "charismatic leader", and "Chinggisid charisma". ${ }^{6}$ In a similar vein, Michal Biran in her "Introduction" to Nomads as Agents of Cultural Change also talks of the "temporary nature" of "supratribal unit such as a nomadic empire" and, the resilience of "the tribal level" and highlights "the notion of divine mandate", "charisma", "the notion of collective or joint sovereignty ... of ruling clan" and "the Chinggisid principle" as the "salient components" of pre-modern Inner Asian political culture. ${ }^{17}$ Moreover, the Weberian idea of "the routinization of charisma" and "the patrimonial household state" have been mobilized to substantiate the charisma theory. While Maria Subtelny, with regard to the Timurid Empire, argued for a transformation of "a loosely administered nomadic empire based on the charismatic personality of the warlord Temür to a centralized polity organized along more rationalized bureaucratic lines", Michael Hope argues for a "process of transition from a temporary political association built around the charismatic leadership of an individual (e.g. Chinggis Khan) to a permanent government supported by laws and traditions" in the case of the Mongol Empire. ${ }^{18}$

Hence, pre-modern Eurasian politics appears almost devoid of enduring impersonal social and political institutions. This image remains powerful even though generations of scholars have scrupulously analyzed many of the institutions of the Eurasian nomadic empires, especially those of the Mongol Empire. Certainly, the conventional bottom-up ethnological paradigm is a major source of this understanding, yet the benign neglect of extant Mongolian sources seems also to have contributed to this representation. The

Golden I982, I991; Di Cosmo I999, Di Cosmo, Frank and Golden 2009.

I5 Twitchett and Tietze I994, p. 45.

I6 Di Cosmo, Frank and Golden 2009, pp. 2, 29, 34, I09, II8, I40, 25I, 280.

I7 Amitai and Biran 20I5, pp. I-9.

I8 Subtelny 2007, pp. II-I5; Hope 20I6, pp. I-2. See Weber I946, pp. 245-52 for charisma and the routinization of charisma. 
relative scarcity of Mongolian sources has made many scholars focus on other sources such as those in Chinese and Persian, yet it has also hindered the examination of the intellectual dimension of the Mongol Empire, such as its political culture.

This article, therefore, by focusing on extant Mongolian sources and examining a concrete story as a window onto the attitudes, beliefs, and sentiments that gave order and meaning to the political processes unfolding at the time, explicating the concrete political concepts (chimar and törü) that provided the underlying assumptions and rules that governed the behaviors of the political actors, and by contextualizing the story within the existing political order, casts light on the political culture, that is, the political ideals and the operating norms of the pre-Chinggisid polity. ${ }^{\text {I9 }}$ The illustration is also corroborated by a comprehensive examination of extant Mongol sources, the accounts of European and Chinese eyewitnesses and later scholarly elaborations. Consequently, in a more concrete case, it argues that the Mongol Khanate was a former Kitan division, and that the Chinggisid power structure and political community were built upon the Kereyid Kingdom, on the remains of the Kitan Empire within the long-standing tradition of Inner Asian statecraft and political culture.

\section{THE STORY}

\section{Temüjin's Messages to Ong Khan and His Allies}

This story to be examined here is not just a random one. It is perhaps the most important section in the Secret History of the Mongols (hereafter SHM), as it is the story of how Temüjin claimed the supreme rulership of the "felt-tent ulus" (sisgei to'urqatu ulus) or the "Mongolic ulus" (mongqoljin ulus) (SHM §202). The story embraces two of the most important battles that Temüjin engaged in on the Mongolian plateau: the battle of Qalaqaljit Elet in spring I 203 in which Temüjin was reduced to "a stray on horseback", and the battle of Jeje'er Ündür's Gorge in autumn I2O3 from which Temüjin emerged as the supreme ruler of the Mongolian plateau. Most importantly, the story details lengthy messages and responses that Temüjin sent to and received from Ong Khan and his allies after his defeat at Qalaqaljit Elet. The messages tell us a great deal about the contemporary political culture, and, it is perhaps one of the most illustrative depictions of the political order and culture that existed on the Mongolian plateau at that time.

Unfortunately, the significance of these battles and of the associated messages has attracted scant scholarly attention. Thus, in this section, I will examine these messages in considerable detail as a window on the political order and culture that then existed on the Mongolian plateau.

In the spring of I 203 at Qalaqaljit Elet, Ong Khan of Kereyid attacked his ally Temüjin, a long-loyal vassal whom he himself had supported as the khan of the Mongols over his rival Jamuqha (SHM: §I70). ${ }^{20}$ The enemies deployed their forces in battle formation,

I9 "Political culture has been defined as a set of attitudes, beliefs, and sentiments that give order and meaning to the political process and provide the underlying assumptions and rules that govern behavior within the political system" (Moisés 20I I, p. 245). 
charged each other hard with waves of different divisions of fresh forces, and engaged in day-long close and bloody combat until Nilqa-Senggüm, the Kereyid crown prince, fell wounded in his cheek at about sunset (SHM: §I70). ${ }^{2 I}$ The Kereyids gathered around him, allowing Temüjin's forces to withdraw (ibid.). The next day, Ong Khan wanted to resume the battle but Achiq-Shirun, the commander of the Kereyid assault division of ten thousand, dissuaded him saying: "Now we [should] heal ... Senggüm. The majority of the Mongols are under us with Jamuqha, Altan and Quchar. The Mongols who fled with Temüjin ... have become strays on horseback who shelter under the shade of trees" (SHM: §I 74). ${ }^{22}$

In retreat, Temüjin sent Arqai-Qasar and Sügegei-Je'ün with oral messages (dawu bari’ulurun) from the eastern bank of Tüngge-Qorqan (Tüngge-Creek) to Ong Khan and his allies Jamuqha, Nilqa-Senggüm, Altan and Quchar, and To'oril (SHM: §§I77, I78, I79, I80, I8I).23 Temüjin, who identifies himself as "son" and addresses Ong Khan as "father", begins his lengthy message with a question, "Out of what cimar did you frighten me?" 24 Then, he complains of how Ong Khan had "frightened" him, namely, "disturbing his sleep", "shortening his bed", and "dispersing his smoke". Next, he denounces Ong Khan for breaking his promise made at Jorqal-Qun that required them "to speak teeth mouth to teeth mouth" and "mouth tongue to mouth tongue" even if they were "envenomed by venomous snake fangs" (SHM: §I77). Then Temüjin castigates Ong Khan declaring, "I do not betray the few for the many; I do not betray the weak for the strong", ${ }^{25}$ and reproaches him: "Was I not like the other wheel of a two-wheeled cart to you, and was I not like the other shaft of a two-shafted cart to you?" (ibid.). Subsequently, Temüjin proceeds to denounce

me who concluded anda with my father". Ong Khan responded by saying that, "In return for the black sable cloak I shall bring your lost ulus to you, in return for the sable cloak I shall bring your scattered ulus under you. Keep your kidney at my buttock, and your phlegm at my chest” (SHM: §96). While Temüjin repeatedly emphasized Ong Khan's anda pact with his father, Ong Khan not only did not reveal a word on the anda pact, but also did not acknowledge Yisügei's recovering his ulus to him. Instead, Ong Khan's response was not only transactional but also demanded Temüjin's subordination. "Keep your kidney at my buttock, and your phlegm at my chest” is figurative language that demands subordination. Thus, though Temüjin clearly sought an anda relationship, based on the existing anda pact, Ong Khan not only rejected it, but instead demanded Temüjin's subordination. Initially, Temüjin seems to have refused it, however, the Merkit capture of Börte-Üjin forced him to accept Ong Khan's demand, which he reiterated when Temüjin arrived, asking his help against the Merkits (SHM: §I04). Ong Khan kept his promise to Temüjin and endorsed Temüjin’s election as the khan of the Mongols over Jamuqha. Temüjin, in his turn, had been loyal to Ong Khan for a long time until the Kögse'ü-Sabraq incident that led to a new pact between Ong Khan and Temüjin at Qara Tün on the Tuul River that raised Temüjin's status to that of an ally to Ong Khan.

2 I Ong Khan deployed the division of jirgin-ba'atud at first, then ten thousand crack troops (tümen tübegen), and then dongqayit ba'atud, followed by a thousand turqa'ud (minqan turqa'ud), and finally his main force (yeke qol or great core). Temujin deployed the division of mangqud in front, followed by uru'ut and, then his main force (SHM §I70). Ba'atud is an advance force (see Atwood 2009) while turqa'ud is an elite force and Chinggis Khan had 8,00o troops or eight divisions of turqa'ud (SHM: §226). Mangqud can be read as a "scare" division as mangqud is a plural of mangqus, a hungry monstrous being (see $S H M \S \S 170$, I95 for descriptions of mangqut and SHM §I95 for mangqus). Uru'ut might have derived from urida, that is, front or advance (see SHM §209).

“morin unu'atan modun nemüreten” (SHM: §I74).

See also Rashiduddin I998, pp. I87-90.

“bi cö'en ber bö'esü olon-ni ülü eri'ülgü büle'e mawui ber bo'esü sayin-i ülü eri'ülgü büle’e bi” means literally "I do not seek the many for the few, I do not seek the good for the bad”. Unfortunately, Cleaves, Onon and Rachewiltz all misread this. 
Ong Khan for earlier breaches of his promises to repay the many critical services that he and his father, Yisügei-Ba'atur, had rendered to Ong Khan when he was in distress. In particular, Yisügei had earlier fought to help Ong Khan regain his kingdom from Gür Khan of Kereyid who had driven Ong Khan out of his kingdom; in return, Ong Khan, in the name of "Heaven and Earth", promised to repay his help for generations to come, and the two sealed an anda (sworn-fellows) covenant. ${ }^{26}$ Later, Temüjin, honoring his father's covenant, helped Ong Khan regain his kingdom after he had been reduced to the status of a destitute vagrant, having been crushed at the hands of Inancha Khan of the Naiman, and renewed his father's covenant at Qara Tün on the Tuul River. ${ }^{27}$ Lastly, shortly before Ong Khan's attack at Qalaqaljit Elet, Temüjin had saved his son and people from capture by the Naiman general Kökseqü-Sabraq at Hula'an-Qut (in the vicinity of Jorqal-Qun), even after Ong Khan had abandoned him on the battlefield. ${ }^{28}$ This led to the treaty of alliance at Qara Tün, the terms of which Temüjin quoted in his message. Temüjin ended his message by demanding Ong Khan explain "out of what cimar of mine did you cimatba" and asked Ong Khan to send him his emissaries "in accordance with the norm of cimar" (cimar-un yosun-tur). ${ }^{29}$

Next, Temüjin proceeded to blame first Jamuqha, and then Nilqa-Senggüm for instigating the rift between him and Ong Khan in rather terse messages to them. It is noteworthy that Temüjin addressed Jamuqha first over Nilqa-Senggüm, the crown prince. Temüjin accused Jamuqha saying, "You [who] hated [me] have separated me from my father, the Khan. The first of us to rise would drink from the blue vase (cung) of the father the Khan. You must have hoped (nayidaba-je) to drink rising before me. Now you may drain the blue vase of my father the Khan, but how much more will you be able to consume?" (SHM: §I79).30 As for Nilqa-Senggüm, Temüjin was rather patronizing and scolded him, brother, fearing for his life, asked for relief from Inancha Khan of Naiman, who, perhaps with the help of Qara-Khitai, invaded Ong Khan, reducing him to surrender to Gür Khan of Qara-Khitai. A year later, Toghril escaped from Qara-Khitai to Mongolia through Uighur and Tangud towns, "milking five goats and sucking camel blood to feed himself", and came to Mongolia with "a single blind qali'un (brownish-grey) horse”. Temüjin saved Ong Khan from this destitution, raising levies for him from his own subjects, letting him winter in his own camp and giving Ong Khan all the war booty from his Merkit campaign (SHM: §§I50, I5I, I52, I77).

While jointly campaigning against the Naiman, Ong Khan, encountering Naiman's Kögse'ü-Sabraq a Baidaraq-belcir, discreetly retreated in the night, leaving campfires on his positions and abandoning Temüjin on the battlefield against the enemy. However, the next morning Kögse'ü-Sabraq, instead of engaging Temüjin, chased Ong Khan, capturing his son Nilqa-Senggüm with his people by defeating Ong Khan. Ong Khan had to ask for help from Temüjin, who recovered Nilqa-Senggüm and his people from Kögse'ü-Sabraq (SHM: §§I59, I60, I6I, I62, I63, I64, I77). "yambar cimar-tur minu cimatba ci”; “cimar-un yosun-tur elcin ile”" (SHM: §I77).

30 The passage points to Temüjin and Jamuqha's rivalry to secure Ong Khan's favor/legacy, and now that Temüjin had eliminated Jamuqha he was "the first to drink". Cung has been translated as either as goblet (Cleaves) or as cup (Rachewiltz and Onon). However, cung (modern Mongolian sön) is a large vase for airag or koumiss usually placed on the table in the middle of ger (yurt). The SHM uses ayaga (cup or bowl) on numerous occasions including Batu's drinking of “one or two ayaga ötök” before Büri and Güyük (SHM: §275). Cleaves, Rachewiltz and Onon translate nayidaba-je or nayidaju as ‘jealous' or 'jealousy'. However, nayidaju (modern Mongolian naidaj or naidakh) means hoping, believing or relying on someone or something. In 
"I am the son who was born with a coat. You are the son who was born bare. [However,] the Khan, our father, cares for us both equally. You, Senggüm anda, chased me away for fear of being supplanted [by me] ... Do not estrange our father the Khan's feeling demanding to become the Khan, not giving up your fixated ambition, while the father, the Khan, is still alive” (SHM: §I8I).

However, Temüjin's message to Altan and Quchar was rather conciliatory or even conceding in tone (SHM: §I79). He displayed his agitation against Altan and Quchar for forsaking him, yet he proceeded to claim that he had been ruling as the khan of the Mongols at their insistence. Temüjin assured them that if Quchar or, especially, Altan, whom Temüjin named as being the coregent with his father Qutula Khan, had accepted the khanship when he had been offered, he would have served him virtuously. In fact, Temüjin was elected by Altan, the son of Qutula Khan, Quchar, the son of Nekün-Taishi, Sacha-Beki and Taichu, the sons of Sorqatu-Jürki (SHM: §I23). While Altan was the son of Qutula Khan and a grandson of Qabul Khan, the rest, including Temüjin, were all great-grandsons of Qabul Khan (SHM: §§49, 50, 51). Thus Altan was the legitimate successor to his father as he was the only remaining son of Qutula Khan and coregent with his father. ${ }^{\text {I }}$ Altan's concession to Temüjin was therefore crucial to his election as the khan of the Mongols and in effect Altan lost his khanship to Temüjin. Afterwards Temüjin executed both Sacha-Beki and Taichu for revolting against him, they having raided his camp while he was away on campaign (SHM: §I36, I37). Subsequently, during a campaign against the Tatars, Temüjin confiscated the war booty of Altan and Quchar, for they had ignored his explicit command (jasaq) not to rush for booty (olja) before defeating the enemy entirely (SHM: §I53). Contemptuous of Temüjin, both Altan and Quchar not only revolted against Temüjin but also conspired with Jamuqha to persuade Nilqa-Senggüm (and Ong Khan) to kill (alaju) Temüjin and to take control of his ulus (SHM: §I66). "Let us take Temüjin's ulus, if he loses his ulus, without ulus what could he do?" they agreed (ibid.). ${ }^{32}$ Thus, it was Altan and Quchar who instigated Ong Khan's attack on Temüjin. Yet, Temüjin, who identified himself as ca'ut-quri33 but not

addition to this occasion, the SHM §I64, 233 uses the word in exactly this sense. On one occasion, however, the $S H M \S 2$ I9 uses it (nayitaju and nayitaqdamu) in a rhetorical way.

“ci altan-i cimayi qutula-qan-lu meden yabulu'a ecige-yü'en meden aqsa'ar ci qan bol” (SHM: §I79).

“temüjin-i ulus inu abuya ulus-iyan abda'asu ulus üge[i]’ü bolu’asu yekikün tede” (SHM: §I66).

Ca'ut quri or ja'ut quri was a title given to Temüjin from the Jin dynasty for his participation in an attack against Tatar (SHM: §I34). Rashid al-Din says it "means magnificent commander" (Rashiduddin I998/99, pp. I64-65). Urgunge Onon rendered it as "Commander of the Ja'ut Territory", ja'ut deriving form Jau, a name of the Jin frontier army, and ut, a Mongolian plural suffix, and Quri being "an Orkhon Turkish word meaning a big chief in command of several tribes" (Onon 200I, p. II3). On the other hand, Atwood claimed that the Jin "dynasty gave Temüjin the Chinese title of Zhaotao, or "Pacification Commissioner" (Atwood 2004, p. 98). However, Ongging-cinsang (Wanyen Xiang), who is said to have given the title to Temüjin, said to him, "Let Altan Khan know if a greater title than this, the title of jeutau (zhaotao), would be given to Chinggis Khan" (SHM: §I34). Thus, obviously Temüjin aspired to the title, however, it is unlikely that Temüjin was granted zhaotao. The title of ja'ut-quri seems to have been similar to the title of digit-quri that the Önggüd ruler Ala-Qush held (see Rashiduddin I998, p. 7 I, also Atwood 2004, pp. 424-25). The spelling of ja'ut appears to be the same as Mongol ja'ut or ja'ud, derived from ja'u, that is, hundred ( $j a^{\prime} u t$ as hundred, see SHM: §§I75, I95, 208, 242, 244). Yet, Kitan chao (perhaps the Kitan pronunciation of $j a$ 'u) was also 'hundred' (Wittfogel and Fêng I949, p. 444). Thus, ca'ut of ca'ut-quri is, perhaps, a pluralized form of ca'u (that is, chao in the Wittfogel and Fêng transcription) while ja'ut of ja'ut-quri is a Mongol form (or pronunciation) of ca'ut-quri. 
as the khan, ended his message in a rather conceding tone by pleading with Altan and Quchar to "Let no one settle at the head of the Three Rivers" (SHM: §I79). ${ }^{34}$ Lastly, Temüjin was most contemptuous of To'oril in his terse and abrasive message; he despised him as an offspring of generations of slaves and derided him, saying, "Whose ulus did you promise to give [to Ong Khan] while you flattered [him]? Altan and Quchar won't let anyone rule my ulus" (SHM: §I80). 35

So what are these messages all about? Was Temüjin complaining and denouncing in rage and conceding in desperation as it appears? Clearly, Temüjin was complaining and denouncing, and his situation appears to have been desperate. However, he was not conceding. Instead, Temüjin was doing something more complex and Machiavellian. He was dealing with cimar. His message to Ong Khan starts with cimar and ends with cimar, and he demands that Ong Khan send his emissaries in accordance with the norms of cimar. At the same time, he was addressing post-Qalaqaljit Elet political reality. So, first, what was cimar?

\section{Chimar: Grievance and Penalty}

Unfortunately, cimar or chimar is lost in modern Mongolian. Thus, examining all the uses of cimar in the SHM and using later dictionary entries on it, I will reconstruct the conceptual meaning of the word. Thankfully, cimar appear several times in the SHM. In addition to this occasion, the SHM uses cimar in $\S \S 108,254$, and 260 and cimarlaqu, cimatba, cimatcu, and cimatqa'asu in $\S \S \mathrm{IO} 8, \mathrm{I} 77,242,254$, and 260 respectively. To launch a campaign against the Merkits, Ong Khan, Jamuqha and Temüjin set up a rendezvous (boljāl, boljalduya) at Botoqan-Bo'orji at the head of the Onon River (SHM §Io6). However, Ong Khan was three days late for the rendezvous. Jamuqha reproached Ong Khan saying, "Haven't we agreed not to be late for the rendezvous even if there be rain, for the meeting even if there be a rainstorm! Haven't we sworn with Mongol 'Yes'? Haven't we agreed to expel the delayer on the 'Yes' from our ranks?" In response, Ong Khan said, "We have been three days late at the place of rendezvous. Let Jamuqha, the younger brother, decide how to reproach and to chimarlaqu!" Thus, [they] talked about the "cimar of rendezvous".

In distributing subjects (irge) to his mother, sons, and brothers, Chinggis Khan gave ten thousand subjects to his mother as his youngest brother's share (qubi), and his "mother did not say [a word] because she was not satisfied (cimatcu) with the share" (SHM §242). When Chinggis Khan, in choosing his successor as the khan, asked Jochi to say his words, Cha'adai interrupted saying, "How could we be ruled by this Merkit's cul ulja'ur?" However, Kökö-chos scolded Cha'adai saying, "If you offend (cimatqa'asu) your mother who has borne you from her heart, the cinar (read cimar) will not cease even if you appease her wailing” ( $S H M$ §254). During the Khwarazm campaign, when Jochi, Cha'adai, and Ögedei

Hence the literal meaning of the title, perhaps, was something of "commander of hundred" or "centurion" meaning "commander of a division", perhaps a combination of Kitan and Turkic elements.

See also Rashiduddin I998, p. I89; “qurban müred-un teri'ün ken-e ber bu bawúlutqun” (SHM: §I79).

When Jamuqha, Altan, Quchar and others proposed that Nilqa-Senggüm attack Temüjin, To'oril suggested to Nilqa-Senggüm, "Let us take Temüjin's ulus; if he loses his ulus, without ulus what could he do?" (SHM: §I66; see also Rashiduddin I998, p. I89). Thus, Temüjin’s message was a response to To'oril's initiative. 
divided the population of Urgench among themselves giving Chinggis Khan no share (qubi), the enraged (kilinglaju) Chinggis Khan did not allow his sons to see him for three days upon their return from campaign because he was offended (cimatcu) by them (SHM §260). Chinggis Khan, who subsequently let his sons see him upon Bo’orchu, Muqali, and Siqi-Quduqu's petition, chastized his three sons with cimar söyü (cimar-i'ar söyü-'er) until Qongqai-Qorchi, Qontaqar-Qorchi, and Chormaqan-Qorchi finally appeased him (ibid.). Both Cleaves and Rachewiltz consistently render cimar in §I77 as 'grievance'.

Though cimar or chimar seems to have been lost in the modern language, cimarlaqu or chimarlaqu was kept until the early twentieth century. According to a Qing-era I7I7 Mongolian dictionary, the verb chimarhamoi is "to demand more upon the acquisition of something”, that is, dissatisfaction and wanting; according to Joseph Kowalewski's I849 dictionary chimarhahu (transcribed as tchimarkhakhou) is jadnichat' in Russian, that is, 'to be greedy', or baryshnichat', that is, to 'haggle' or 'bargain for more'. ${ }^{6}$ Finally, Shagj's I929 dictionary has chimarhamui as "to demand for more upon acquisition of something; also, to complain again once a matter has been completed". 37 On the other hand, cimatcu or chimlakhu, preserved in modern Mongolian, conveys a feeling of dissatisfaction, discontent, and displeasure. As the cited passages evidently show, the SHM used cimatba, cimatcu, and cimatqa'asu to clearly express the feeling of dissatisfaction, discontent, and displeasure, or as Kökö-chos's usage demonstrates cimatqa'asu is offending, hurting, or wounding, as Cha'adai did to his mother, while chimar is the result of offending, a grief, sorrow, or wound that, as Kökö-chos claimed, would never go away even if Cha'adai wailed to appease his mother. Thus, cimar, as Cleaves and Rachewiltz correctly rendered it, was grievance. However, there seems to have been more to it than the feeling of grievance alone.

When we look at Jamuqha and Ong Khan's exchange, cimar, and cimarlaqu (to do cimar with it or by it), refer to the clause of their agreement that required those who failed to keep their oath to be expelled from their ranks: a penalty. Not only dissatisfied (cimatcu) with Ong Khan's failure to arrive on time to the rendezvous, but also exploiting this rare opportunity, Jamuqha, with his legitimate grievance (cimar), deployed his forces of twenty-thousand strong in battle formation in order to penalize (cimarlaqu) Ong Khan. Clearly his forces must have been well rested and prepared during the three days, and must have occupied the best possible position. When Ong Khan, who clearly did not expect such a turn of events, hurriedly deployed his twenty thousand against Jamuqha's forces, his men and horses must have been exhausted from the long march and in a disadvantageous position. Furthermore, both the oath and the clause were on Jamuqha's side. Thus, Ong Khan was forced to yield to Jamuqha, a far more junior and lesser lord, to the point that he had to let Jamuqha administer the cimar as he saw fit. The SHM does not say if Jamuqha indeed punished Ong Khan, or what his penalty (cimar) was..$^{38}$ Thus, cimar

36 Qorin nigetü tayilburi toli I979, p. 768; Kowalevski I849, p. 2 I68.

37 Shagj I998, p. 782.

38 As Paul Ratchnevsky noted, Jamuqha's relationship to Ong Khan had been "that of a younger brother" whereas Temüjin was simply forced to be that of "son-to-father"; Ratchnevsky I99I, p. 36. Thus, Ong Khan, as an overlord, commanded Jamuqha to join the Merkit campaign with twenty thousand men. Now, however, he was penalized by his "younger brother". Furthermore, at the beginning of the campaign Temüjin was with Ong Khan while Jamuqha was raising ten thousand men from Temüjin's ulus. However, at the end of the campaign, Temüjin was accompanying Jamuqha (see ibid., pp. 3I-39). We do not know 
had a derived meaning of penalty or reparation, one derived from a grievance that arose from a violation of commonly accepted norms and, especially, of a formal relationship such as a treaty.

This reading can be corroborated by another interesting use of cimar in the SHM §260. As mentioned above, in chastising his three sons, Chinggis Khan berated them with or by cimar and söyü (cimar-i'ar söyü-'er). In this binomial usage, which is very common in Mongolian and indeed in the SHM, söyü clarifies the meaning of cimar. In a Mongolian binomial expression, the second word usually clarifies the meaning of the first word when a speaker wants to convey a meaning that is usually not the conventional meaning of the first word. In cimar-i'ar söyü-'er, -i'ar and -'er are instrumental markers, thus -i'ar and -'er mean "by means of", consequently, cimar-i'ar söyü-'er means by means of cimar and söyü.39 Aside from this occasion, the SHM uses söyü in $\S 22$ and $\$ 277$ as söyü-'er and in $\$ 227$ as süyitügei (twice) and söyü'et, and in \$278 as süyütügei, söyütügei, söyü'et, and söyüt-je in verb form. In §22, Alan-Qo’a took to task her five sons, and in \$277 Ögedei and his son Güyük, just as Chinggis Khan did his three sons in §260. The passage in $\$ 277$ is Ögedei’s reiteration or reaffirmation of Chinggis Khan’s initial decree (jarliq) in $\$ 227$ that promulgated punishments to guards who neglected their duty. If a guard neglects his duty for the first time, punish (süyitügei, süyütügei) him with three strokes of the rod (beri'es), for the second time, punish (süyitügei, söyütügei) him with seven, and for the third time, send him to a distant place after punishing (söyü'et, söyü'et) him with seven strokes. "If [kesiqten] breaks a law (jasaq) inform us; if he must be put to death we shall execute him, if he must be disciplined we shall punish him (söyüt-je)", reads the last case.

Thus, cimar had a derived meaning of punishment or penalty for injustice or violation of commonly accepted norms. Temüjin's demand that Ong Khan send his "emissaries in accordance with the norm of cimar" makes sense only in this reading. If Temüjin's message was only his declaration of his grievance, which it certainly was, he would not have demanded Ong Khan to send his "emissaries in accordance with the norm of grievance”. There was no need for Temüjin to learn Ong Khan's ex post facto rationalization of his attack. Instead, what Temüjin was doing was demanding that Ong Khan send his "emissaries in accordance with the norm of penalty", or exact war penalty or war reparation.

Thus, Temüjin was formally declaring his grievances "in accordance with the norm of grievance" to Ong Khan and he was also demanding a war reparation "in accordance with the norm of penalties" from him. Temüjin was meticulous in his listing of Ong Khan's vices point by point. While "out of what grievance did you frighten me" was a condemnation of unjustified attack, "disturbing one’s sleep", "shortening one’s bed”, and "dispersing one's smoke" was a denunciation of undeclared onslaught. The very fact of these

if this arrangement was a part of Jamuqha's cimar. Clearly, Temüjin, who was not content with his subordination to Ong Khan, must have sought anda alliance with Jamuqha to lessen his dependency on Ong Khan. However, about a year later Temüjin broke with Jamuqha, and in a few months, he, in his early twenties, was elected as the khan of the Mongols over Jamuqha. Ong Khan endorsed his election, while the outraged Jamuqha subsequently routed Temüjin at Dalan Balzhut, forcing him to seek refuge along the Jin frontier. Eventually, Jamuqha was enthroned as Gür Khan (see Ratchnevsky I99I, pp. 47-54; Munkh-Erdene 20II, pp. 225-29). 
questionings shows that there was a commonly accepted norm to start hostilities on the basis of legitimate grievance, and also a norm to declare war before launching an attack. Thus, both attacking without legitimate grievance and attacking one's adversary without prior declaration of war were violations of commonly accepted norms. If these were not commonly accepted norms, these questionings would have never emerged. Only after laying out Ong Khan's violations of commonly accepted norms did Temüjin turn to Ong Khan's breaches of their mutual agreement. Even in this, Temüjin is meticulous in charging Ong Khan on two counts: his violation of the provision to resolve any grievance in a face-to-face meeting and his betrayal of his ally. Still, Temüjin, chastising Ong Khan on his numerous earlier renegings on his promises, and on his violations of his alliance treaties, substantiates his charges. In declaring "I do not betray few for many; I do not betray weak for strong”, and in enumerating his and his father's enduring fidelity to their words and treaties, Temüjin was not only contrasting himself with Ong Khan, but also was portraying himself as a righteous and virtuous ruler. Thus, the SHM was using the term for grievance-penalty (cimar) repeatedly and consistently and, indeed, Temüjin's message was his formal declaration of his grievances and Arqai-Qasar and Sügegei-Je'ün were his emissaries (elcin) sent to Ong Khan "in accordance with the norm of grievance and war reparation".

\section{A Political Warfare: The Kereyid and Mongol Inheritances}

At the same time, in delivering messages to Ong Khan's allies, Temüjin, addressing a post-Qalaqaljit Elet political world, a world without Temüjin, was conducting psychological or political warfare against Ong Khan and his allies to pit his enemies against each other. $4^{\circ}$ However, a proper reading of Temüjin's messages requires a precise understanding of the post-Qalaqaljit Elet political world that Temüjin was addressing.

Temüjin had not just been routed and forced into a retreat; he was overthrown as the khan of the Mongols and eliminated as a potential successor to the Kereyid throne, reduced to "a stray on horseback", a fugitive. Temüjin's retreat to the Khalkha River looks more like a flight than a retreat (SHM: §§I7I, I72, I73, I74, I75, I76, I77). ${ }^{4}$ When Temüjin counted his men at Dalan-Nemürges before he fled farther to the Khalkha River, he had only 2,600 men and was constantly on the alert and hiding while retreating (SHM: §I75). SHM §I83 tells how his brother Qasar had a hard time finding Temüjin, searching for him everywhere. As Achiq-Shirun claimed, "The majority of the Mongols ... with Jamuqha, Altan and Quchar” were under Ong Khan while Temüjin not only took refuge in the basin of the Khalkha River and Buir Lake, which was the territory of the Onggirats, but was also begging Altan and Quchar, "Let no one settle at the head of the Three Rivers", the hearth of the Mongol khanate (SHM: §I79). Moreover, Temüjin was telling To'oril, "Both Altan and Quchar won't let anyone rule my ulus" (SHM: §I80). He had been eliminated as a

40 Psychological or political warfare is understood here as "any action which is practiced mainly by psychological methods with the aim of evoking a planned psychological reaction in other people ... influencing people's belief, mentality, and attitude, or transferring an idea, mentality, or attitude by written and spoken words or by behavior" (Szunyogh I955, pp. I3-I5).

4I Temüjin retreated from Qalaqaljit Elet to Ulqui-Silügeljit, and then further to Dalan-Nemürges, then to the Khalkha River, and to Tüngge-Qoroqan. 
power to be reckoned with. Hence, the world without Temüjin, especially the question of Temüjin's potential successor to the Kereyid throne and the khan of the Mongols, was on the agenda.

Not long before Qalaqaljit Elet, and right after the Kögse’ü-Sabraq incident, Ong Khan, grateful to Temüjin and worried about "who would rule all the ulus when I depart [this world]", had contemplated making "Temüjin an elder brother to Nilqa-Senggüm” (temüjin kö'ün-i senggüm-ün aqa bolgoju), and held an assembly with Temüjin "to negotiate [the terms of] father and son" at Qara Tün (SHM: §I64). The accord or "the norm (yosu) to negotiate father and son" that the parties struck was modelled after the accord of anda between Ong Khan and Yisügei, and made Temüjin an ally of Ong Khan. The provision that stipulated the parties meet face-to-face if there emerged any suspicion or a third-party intrigue aimed at destroying their mutual trust, for which Temüjin held Ong Khan responsible, was a part of this pact (SHM: §I64).4² Obviously capitalizing on the Kögse'ü-Sabraq incident, Temüjin had not only forced Ong Khan to recognize himself as an ally by anda but also made him acknowledge that Temüjin was a worthy successor to him. Thus, in telling Nilqa-Senggüm, "I am the son who was born with a coat. ... the Khan, our father, cares for us both equally. You, Senggüm anda, chased me away for fear of being supplanted by me”, Temüjin was alluding to this promise. Ong Khan must not have been content with this new arrangement, while Nilqa-Senggüm must have been alarmed by Temüjin's ambition. Thus, Nilqa-Senggüm was threatened with being supplanted by Temüjin as a successor to the Kereyid throne. At the instigation of Altan, Quchar and Jamuqha hatched a plan to remove Temüjin. Ong Khan, who is said to have repeatedly objected to the scheme, declaiming that "we won't be favored by Heaven",43 finally yielded to his son after Nilqa-Senggüm confronted him with the question, "Would [Temüjin] allow me to rule the ulus that your father Qurcaqus Buyuruq Khan labored to assemble?"44 Though Ong Khan and Nilqa-Senggüm had eliminated Temüjin as a potential successor to the Kereyid throne, the succession question had not yet been settled. To solve this question, the problem of the Mongol khanship, the most salient of Temüjin's legacies, had to be resolved.

For years, Ong Khan had been pitting one Mongol aristocrat against the other to keep the Mongols divided. To check Jamuqha, Ong Khan had earlier sponsored Temüjin as the khan of the Mongols over Jamuqha, who was growing increasingly powerful and assertive. Later, to control Temüjin, Ong Khan kept Jamuqha after his Gür-Khan enterprise. 45 Yet, in endorsing Temüjin as the khan of the Mongols, Ong Khan was also raising Temüjin over the legitimate successor and coregent Altan, the son of Qutula Khan, dashing his hopes to succeed his father as the khan of the Mongols. Ong Khan, who was not on good terms with Qutula Khan, seems to have prevented Altan from succeeding his father after Qutula's demise, instead promoting Jamuqha, who was lacking genealogical legitimacy, over

See also Rashiduddin I998, p. I88 for this pact.

"tenggeri-de ülü ta'alaqdaqun bida" (SHM: §I67).

44 “qurcaqus-buyiruq-qan ecige-yin cinu joban edüi quriyaju aqsan ulus-i cinu man-a-'ú mede’ülgü” (SHM: §I67). 
Altan. ${ }^{4}$ When Jamuqha grew strong and assertive, Ong Khan promoted Temüjin, the son of his erstwhile anda Yisügei. To free themselves from Jamuqha's domination, Altan and Quchar together with Sacha-Beki and Taichu proceeded to raise Temüjin, who was the youngest and weakest of all the Qabulid princes, as the khan of the Mongols. They, like Ong Khan, thought to manipulate Temüjin. However, Temüjin proved himself to be much more able, ambitious, and autocratic than Jamuqha. Thus, Altan was not only contemptuous of Temüjin but was also conspiring to get rid of him in order to reclaim his legitimate throne. Just as Temüjin's rise curtailed Jamuqha's fortunes, so his downfall would free Jamuqha. Thus, everyone wanted to eliminate Temüjin. Jamuqha knew both Ong Khan and Nilqa-Senggüm's fear and Altan and Quchar's intention. Hence, he engineered the anti-Temüjin coalition.

Yet, the allies also each harbored their own respective plans, especially Ong Khan. While Altan hoped to reclaim his khanship using Ong Khan's forces, Ong Khan and Nilqa-Senggüm's aim was to swallow the Mongol Khanate, as Achiq-Shirun's claim shows. Both Jamuqha and Altan were aware of the danger, and that they were to face the Kereyids after Temüjin's elimination. With Temüjin eliminated, Jamuqha would reemerge as a key player. While an uncontrolled Jamuqha was a threat to everyone including Altan, Jamuqha's ultimate target was the Kereyid throne as his failed Gür Khan enterprise demonstrated. The situation must have been tense and volatile.

Temüjin, as the khan of the Mongols and a contender for the Kereyid throne, knew this well and was trying to accelerate their eventual showdown by exacerbating the tensions. Hence Temüjin was not only getting on Ong Khan's nerves by pitting Jamuqha against Ong Khan, but was also openly challenging Jamuqha: "Now you may drain the blue vase of my father the Khan, but how much more will you be able to consume?" According to Mongolian custom (yosu), emptying or draining sön (a kumiss vase), and even a kumiss bowl (ayaga or khul) is considered an offence. Whenever there is a need to empty the sön, what is left in the bottom is sacrificed to Heaven as a libation by spraying it into the sky (saculi sacun, modern Mon. tsatsal tsatsah). The libation (saculi or tsatsal) is usually the prerogative of the lady of the house. If our reading of this passage is correct, this custom seems to have been well established at this time. In fact, Temüjin made saculi öciüli (the libation pledge or promise) to Burqan-Qaldun after his escape from the Merkit attack (SHM: §Io3). Thus, "Now you may drain the blue vase of my father the Khan, but how much more will you be able to consume?" was Temüjin's way of challenging Jamuqha to take the Kereyid throne.

In addressing Jamuqha first, thus giving primacy to him over the crown prince, and in patronizing Nilqa-Senggüm to wait until his father died, Temüjin was not only inciting the crown prince against Jamuqha but also exacerbating Nilqa-Senggüm's restiveness that he might be supplanted by Jamuqha and miss the chance to become the next Ong Khan. However, as for Altan, Temüjin was encouraging him in his claim for the khanship. Thus, Temüjin was making it sound as if he were abdicating in favor of Altan, whose

46 According to Rashid al-Din, when Toghril came to Yisügei fleeing from his uncle Gür-Khan, Qutula Khan told Yisügei, "Friendship with him is not advisable ... for we know him. It would be better to become anda with Gür-khan, for he is a gentle man with a good disposition. This man killed his own brothers and sullied his lance with their blood. Now that he resembles a wild ox struck by an arrow and a wild ass with an aghruq around its neck, he has come under our protection" (Rashiduddin I998, p. 63). Clearly, Ong Khan had reason to disrupt the Qutulid reign over the Mongols. 
legitimacy Temüjin established by designating him as the successor to and the coregent with Qutula Khan. In pleading with Altan and Quchar to "Let no one settle at the head of the Three Rivers", Temüjin was thus urging Altan to keep his principality for himself only. Temüjin made sure that everyone knew that he was "abdicating" in favor of Altan. For this reason, through To'oril's mouth he was declaring to Ong Khan that "Altan will not let you to rule his ulus" by intentionally humiliating To'oril so that he would immediately reveal Altan's "intention” to Ong Khan. Thus, Temüjin was pitting his enemies against each other, fomenting their anxieties and mistrusts, and especially pitting Jamuqha and Altan against Ong Khan and his restive son. Whether Temüjin's stratagem played a role or not, the question of his inheritance showed its importance, soon making Temüjin's enemies fight with each other. According to Rashid al-Din, Jamuqha, Altan, Quchar, and others conspired, saying, "Let's launch a surprise attack on Ong Khan and become rulers ourselves"; however, Ong Khan preemptively attacked them. Defeated, Jamuqha, Altan, and Quchar found refuge with Tayang Khan of Naiman. ${ }^{47}$ Now the time was ripe for Temüjin, who had been waiting for this moment.

In the autumn of I203, Temüjin, who had reinforced his remaining 2,600 men with the Onggirat and the Qorulas, made a surprise ${ }^{48}$ night assault on Ong Khan at the mouth of the Jeje'er Ündür Gorge, and after three days' battle he emerged victorious. Ong Khan, on the run, was killed by Qori-Sübechi, a Naiman border guard, at a place called Nekün Usun. Nilqa-Senggüm was abandoned in the middle of the desert without a horse by his master of horse (aqtaci); Kököchü Temüjin was immediately executed for betraying his own sovereign (SHM: §I88).49 Thus Temüjin, who had once been reduced to "a stray on horseback", not only reclaimed his Mongol Khanate but also claimed the Kereyid throne.

Subsequently, Temüjin crushed Tayang Khan of the Naiman, who not only accused Temüjin of usurping the throne of Ong Khan, having forced the "ancient old great khan" to die, but also marched against him exclaiming, "How can there be two khans on Earth?” (SHM: § I89).50 Jamuqha was captured and brought before Temüjin by his entourage (nököt). In accordance with his own wish, Jamuqha was put to death in a noble way. Yet Temüjin summarily executed those who betrayed Jamuqha as "commoner slaves" (qaracu bo'ol) who "put their hands on their sovereign" (SHM: §200). While SHM §I79 indicates Altan and Quchar's unhappy ending, Rashid al-Din reports that Temüjin put to death Altan and Quchar, who were allied with Tayang Khan.5' ${ }^{\text {I }}$ Thus Temüjin claimed the supreme rulership of the "Mongolic ulus".

See Rashiduddin I998, pp. I90-9I.

Temüjin made sure that Ong Khan let his guard down by sending him messengers on Qasar's behalf. The messengers, Qali'udar and Caqurqan, told Ong Khan that Qasar requested to submit to Ong Khan because he could not find his brother after searching for him everywhere and because his wife and sons were under Ong Khan. Thus Qasar's brother Temüjin had disappeared or was gone. Satisfied, Ong Khan sent them back with his own messenger to Qasar and started to feast, setting up a Golden Tent (SHM: §§I83, I84, I85).

9 See also Rashiduddin I998, pp. I9I-92.

Rashid al-Din has it as "On the earth how can there be two monarchs in one Kingdom?" (Rashiduddin I998, p. 20I).

I Rashiduddin I998, pp. 67, I33. 


\section{THE PLACE}

\section{The Zubu-Kereyid Kingdom}

The demise of the Kitan Empire (907-I I 25) left, on the one hand, the Zubu, 52 a former "subordinate state" to Kitan, and on the other, numerous Kitan top-down military-administrative divisions, or what Wittfogel and Fêng called "synthetic or composite tribes", on the Mongolian plateau around the middle of the twelfth century.53 When Temüjin came on the scene, the Zubu-Kereyid Kingdom - the regional hegemon under Ong Khan - was aggressively campaigning to incorporate the former Kitan divisions who in their turn were in the process of transforming into autonomous principalities. Toghril, the last Ong Khan, seems to have been a very competent ruler: he was not only able to establish Kereyid hegemony but also to overcome the Liao divisive legacies in the face of the Qara Khitai and the Jin disruptive interventions. If we approach the Chinggisid sources critically, we see that it was actually Ong Khan who was incessantly campaigning to subdue the Merkit, Tatar, Gür Khan, Merkit, Naiman, and Mongols (See SHM: §§ I05, I 33, I42, I44, I57, I 58). 54 As a result, Ong Khan managed to revive the hegemony of Kereyid power over Mongolia, and made the Jin court recognize his status as the "king of the realm" with the title of Wang, the title that his grandfather Markhuz had won from the Kitan court.

The Chinggisid name of this kingdom is Kereyid - perhaps a belittling form of the name of the ruling house, whereas Zubu was clearly a Kitan provincialization. 55

52 If, as Wittfogel and Fêng claim (I949, pp. IoI-2), the Tibetan word 'Sogpo' for Mongolia is derived from Tsu-pu (or Zubu) or Tsu-p'u, Zubu seems to have been the name of the kingdom or country. If that is the case, Kereyid must have been the name of its divisions (or ruling house) just like Chakhar, a sort of Chinggisid belittlement of Ong Khan. If that was the case, 'Mongol' must have displaced Zubu as the name of the state and realm. It should be noted that Zhao Hong, a Song envoy, who visited Muqali's headquarters around I22 I, reported that the 'Mongols' knew themselves only as Tatars and they call their state Da Menggu guo 大蒙古國 after a long-collapsed empire (Munkuev I975, pp. 53, 249). Furthermore, it is worth noting that Atwood (2010a, p. 609) finds zhubu 諸部, that is, “units" in the writings of the ninth-century Tang author Li Deyu 李德裕 (787-850) who used it along with buluo 部落 “local followings”,.. buxia 部下 or buwu 部伍 or units in the military service” in his writings on frontier issues. Wittfogel and Feng (ibid.) wrote that Tsu-pu was a Liao designation for Tatars and was “written in the Liao Shih [as] 阻卜 and Tsu-p'u 阻䪁 in the Chin Shih". Thus, ultimately, Zubu might have been a corrupted derivation of Tang zhubu 諸部, that is, “units” or "divisions". If this is the case, then, as Fêng Ch'êng-chün believed, zhubu must have been just a generic or "collective term" for frontier military-oriented divisions including Kitan frontier divisions, simply meaning 'divisions' (ibid.). Or it might have been the common name for all the divisions under the hegemony of the Kereyid house as there were eighteen divisions of Zubu. Later in the seventeenth century, Manchus uniformly categorized former Mongol tümens and otoqs as ayimaq (division) (Atwood 201ob; Munkh-Erdene 20I6).

53 Though the Liao collapsed in II25, its presence in Mongolia seems to have been enduring. Yelü Dashi, the founder of Qara-Khitai, made Kedun, a Liao military garrison, his power base during I I24-I I 30 and seems to have organized the area under his control into "seven prefectures" (Biran 2005, pp. 26-33).

54 If we follow the order of the events in the SHM, Chinggis Khan's own military achievements were quite modest. He suffered a crushing defeat at the hands of Jamuqha at Dalan Baljut (SHM: §I29). The only significant victory that he achieved was over Tatar (SHM: §§I 53, I 54). It is true that he beheaded Jürkin rulers and defeated Tayichiut (SHM: $\S \S$ I 36, I 44). However, the Jürkin rulers did not give battle, whereas Tayichiut was in retreat after they were defeated by Ong Khan’s forces. Furthermore, Jürkin and Tayichiut were only minor forces.

55 With regard to the conversion of the Kereyids to Christianity in I007, Erika Hunter suggested that Kereyids were "not the original subject of the conversion episode", rather it was later interpolation by Gregory Abu'l Faraj, or Bar Hebraeus (Hunter I989, p. I43). 
According to Rashid al-Din, Kereyid was a name of the ruling lineage of the Kereyids whose "ancient monarch had eight sons, all of whom were dark-skinned for which reason they were called Kerayit”, while folk etymology derives it from the Turkish qara-et, 'blackflesh'.56 The Kereyid ruling family were Christians of the Nestorian tradition. As Nestorianism is a Christological doctrine, Kereyid might also have been a Mongolized plural form of Kyrios or "Lord", thus, Kyriod or Kereyid.

Toghril, the Ong Khan, was the last ruler of the Zubu-Kereyid Kingdom, while his grandfather was one of the earliest known Ong Khans of the Zubu. According to Rashid al-Din, Toghril's grandfather Marghuz (Markos or Marcus) Buyuruq Khan, the ruler of the Kereyid, was captured by Na'ur Buyuruq Khan of Tatar, a vassal "to the monarchs of Cathay and the Jurchids" 57 and was "sent to the King of the Jurchids, who had him killed by being nailed to a wooden donkey". ${ }^{58}$ According to the Liao shi, in I089 Kitan recognized Mo-ku-ssü, a Zubu ruler, as "the chieftain of various tribes" or, more properly, as the Great King of the Zubu, a "subordinate state" to Kitan since Zubu was categorized as a "subordinate state" and its ruler was addressed by Kitan as the "Great King". ${ }^{59}$ However, Mo-ku-ssü soon invaded Kitan and destroyed the greater part of the Kitan army in I093, and continued to war with Kitan until he was captured by Yelü Wotela in I Ioo and sent to the Kitan court to be "hacked to pieces in the market place". This Mo-ku-ssü was none other than Marghuz Buyuruq Khan, who was clearly betrayed by the Tatar ruler. ${ }^{60}$ The native title of the ruler of Zubu must, surely, have been 'Khan'. The Kitan title of “Great King” was obviously attached to the native title as a qualifier, thus creating Wang Khan (King Khan), which appears in the SHM in the form Ong Khan. Thus, the Jin dynasty's conferral of the title of Wang upon Toghril Khan was in fact nothing but the Kitan's successor's confirmation of Toghril's inherited title of Wang (King) or Ong.

Though Zubu checked Kitan's westward expansion, ${ }^{6 \text { I }}$ it also suffered from Kitan's divide-and-rule policy. After two decades of turbulence following the Kitan emperor Shengzong's campaign against Zubu in 983, Kitan achieved the surrender of the Zubu Khan in 1003 and divided the realm "into several divisions, each under a Liao military governor". ${ }^{62}$ Later on, fighting against Markhuz, Kitan mobilized "tribal soldiers" against him in 1092 and eventually won over many of Markhuz's former allies against him. ${ }^{63}$ With the collapse of the Kitan Empire, the Zubu or Kereyid Kingdom, under Toghril's

56 Rashiduddin I998, p. 62.

57 Rashid al-Din's Cathay is Kitan from Mongolian Kitat or Kitad, however, the SHM did not differentiate Cathay from Jurchids as the phrase "Altan Khan of Kitat irgen” (kitat irgen-ü altan qan) shows (SHM: §I32).

58 Rashiduddin I998, pp. 62-63.

59 Wittfogel and Fêng I949, pp. IOI-2, 317, 593; Twitchett and Tietze I994, pp. I38-40; see also Togan I998, pp. 65-7I.

60 See also Atwood 2004, pp. 295-97.

6I Although defeated by the Kitan founder Abaoji in 924, Zubu checked Kitan expansion westwards by constantly warring with Kitan. Thus, Zubu must have been a considerable power to have been able to deter Kitan advance. Furthermore, according to Abu'l Faraj, by I007 when the Kereyid ruler converted to Christianity, he had 200,000 followers (See Hunter I989, p. I56; Togan I998, pp. 60-61, Atwood 2004, p. 296).

62 Mote I999, p. 57.

63 Wittfogel and Fêng I949, pp. 518, 362, 593-94. 
father Qurcaqus (Kyriakos or Cyriacus) Buyuruq Khan, had emerged as the dominant power in the region. ${ }^{64}$

\section{Kitan Divisions and the Mongol Principality}

While the Zubu or the Kingdom of Ong Khanid was a Kitan "subordinate state", most of eastern Mongolia had been a part of the Kitan Empire for over two centuries. Kitan Mongolia was organized into "tribes", and those that were part of the fifty-four "imperial tribes" were under the Kitan "Northern Administration". ${ }^{5}$ Furthermore, while "barbarians" formed a significant proportion of the ordo ${ }^{66}$ troops of the Kitan emperor, "Mu-tsung's ordo garrison is known to have included Tsu-pu (Zubu) tribesmen". ${ }^{67}$ A number of these "tribes" are identified as residing in Mongolia. ${ }^{68}$ Scholars have suggested or even identified some of them as being Kereyid (northern Tsu-pu), Mongol, Jajirat, Naiman, Dörben, Uriangkhai, Negüs, Merkit, and Ongirat. ${ }^{69}$ Biran, with regard to the Kedun period, identifies "Onggirad, Jajirad, Merkid and Zubu". ${ }^{\circ 0}$

Yet, Kitan "tribes" were top-down creations. Kitan rulers literally built the imperial fiftyfour "tribes” ( $b u$ 部). They divided "relatively large tribal groups" into a number of smaller "tribes", abolished "tribal statuses", and "gathered together small fragments or even individuals and formed them into new groups", granting them "tribal status" ${ }^{71}$ For example, in one case, "Each of the old eight Ch'i-tan [Kitan] tribes contributed twenty households to a special garrison which, after expanding considerably, developed into the T'eli-t'e-mien tribe”. Kitan rulers mixed subjugated non-Kitans into Kitan "tribes" and, indeed, seven of the eighteen T'ai-tsu's tribes "were all composites". ${ }^{2}$ Thus Wittfogel and Fêng use terms such as "synthetic tribes" or “composites”. Indeed, they elaborate that “Tsu [⿰⿱丶万⿱⿰㇒一⿱⿰㇒一大 $p u$ are Chinese terms that are nothing more than approximate equivalents for specific and sometimes unfamiliar aspects of Ch'i-tan society. The term $p u$ is used as an equivalent for pu-lo 部落, tribe; it may also be used to mean a local group or an administrative unit”. In fact, they define tribe as "aggregates of a number of local groups, held together by the need for joint military action, by the authority of a head chief". ${ }^{73}$ Kitan "tribes" were subdivided

64 As Nilqa-Senggüm's words, "Would [Temüjin] allow me to rule your ulus that your father Qurcaqus Buyuruq Khan labored to assemble?", show, Toghril's father Qurcaqus, the commander khan, seems to have revived Zubu or Kereyid dominance, overcoming Kitan divisive legacy (See Atwood 2004, pp. 295-96).

65 Wittfogel and Fêng I949, p. 453.

66 Whether the Mongol ordo developed from Kitan ordo directly, or "were both variants of an earlier common form", it is hard to prove that the Mongol ordo was immune to that of the Kitan when the greater part of geographical Mongolia with its demography was part of the Liao while the remaining part of Mongolia was under Liao hegemony (Wittfogel and Fêng I949, p. 2I).

67 Ibid., p. 55 .

68 Ibid., pp. 87-III.

69 Paul Pelliot considered the term Mei-ku-hsi 梅古悉 “one of the early forms of the word Mongol” (ibid., p. 9I).

70 Biran 2005, pp. 28-29.

7 I Wittfogel and Fêng I949, pp. 46-48, 85-86.

72 Ibid., p. 48.

73 Ibid., pp. 46-48. 
internally and the smallest division seems to have been a chao74 or "hundred". ${ }^{75}$ Thus, Kitan "tribes" were nothing but government-created top-down numerical (obviously decimal) divisions. Indeed, Atwood has recently shown that the Yuan-era compilers of the Liao shi were meticulous enough to elaborate on the nature of the Kitan buluo 部落 and buzu 部 族 as top-down administratively-created territorial or residential units. ${ }^{76}$ Strikingly, he cogently demonstrates that Kitan-era Chinese authors were using buluo or buzu to describe divisions that precisely lacked a stable long-lasting kinship organization, and in fact for them "the relation of corporate kin groups to ... state-building was exactly the opposite of that assumed in nineteenth-century European social science. Strong, multi-generational descent groups depended on the state ... for their very existence. Building a stable state involved not breaking down long-lasting corporate lineages, but building them up".77 Thus, ironically, in the Chinese thought of the era, multi-generational descent groups or kinship organization was the foundation of the state, not an impediment to the state or a sign of its absence.

"[The Kitan] tribes were administered by a senggüm (xiangwen, from Chinese xianggong, 'lord chancellor'), assisted by a lingqu (lingwen, from Chinese linggong, 'lord director') and staff". ${ }^{8}$ According to $S H M \S 47$, while Toghril's son Nilqa was senggüm, revealingly the Mongols Caraqai-lingqu and Senggüm-Bilge were father and son. ${ }^{79}$ Evidently, Caraqai's son Bilge was promoted to be the commander of a Mongol division (hence Senggüm or Commander Bilge), that is, a Kitan "composite tribe”, while his father served as an assistant to the commander (hence lingqu or Caraqai-assistant). What is more telling, of course, is that Bilge's son Ambaqai was elevated as the khan of Qamuq Mongqol (All Mongol), while most telling of all is that Temüjin was their successor as the khan of Qamuq Mongqol (SHM: §52). Thus, we can locate the origin of the Mongol polity in a Kitan division, and the origin of Chinggis Khan in the lineage of Kitan commanders.

Perhaps this was one of the reasons why so many Kitans, starting from Yelü Ahai, and his brother Yelü Tuhua, Yelü Nieers, Yelü Liuge, Shimo (Xiao) Ming’an, Shimo Yexian, and Yelü Chuzai and others with their followers so readily joined and loyally served Temüjin in his enterprise. ${ }^{80}$ For instance, Yelü Liuge joined Chinggis Khan in I2 I 2 with an army of Ioo,ooo men. ${ }^{81}$ In I225, Chinggis Khan is reported to have said about his son, "Xuedu is

"Chao means 'hundred'; originally the term may have indicated the number of families living in an encampment; but in later usage it merely designated a tribal subdivision containing perhaps 'hundreds' of families". (Wittfogel and Fêng I949, p. 444). Kitan chao (perhaps ca'u) is clearly Mongolian ja'u and, indeed, in the SHM $\S I 79$, Temüjin's title ja'ut-quri is spelled as ca'ut-quri.

Wittfogel and Fêng I949, pp. 444-45.

Ibid., p. 603 .

Atwood 2004, p. 3 I7

We also find other Kitan titles such as Taishi, tekin, and tarqan in pre-Chinggisid Mongolia (see Wittfogel and Fêng 1949, pp. 442-45 for these Kitan titles). For example, we find Nekün-Taishi, Qada'an-Taishi (both Mongol), and Alin-Taishi, Qori-Silemün-Taishi and Tai-temür-Taishi (all Kereyid) in the SHM (SHM: §§50, 53, I52, I70, I77). Tai-temür was Ong-Khan Toghril's slain brother.

See Ratchnevsky I99I, pp. I03-44; Biran 2015; Atwood 2004, pp. 599-60I. 
already a Mongol”. ${ }^{22}$ In fact, as Zhao Hong wrote, “The Tatars (Dada 鞋靼) admire the Mongols (Meng 蒙) as a martial nation (xiongguo 雄國), thus they designate the name of the state (guohao 國號) as the Great Mongol State (Da Mengguguo 大蒙古國). They were taught by defected Jurchen (Ruzhen 女真) officials about it”.83 Zhao Hong's Jurchen or Jin officials were none other than Kitans such as Yelü Ahai and Yelü Tuhua, whom Zhao Hong identified as Jurchen officials. ${ }^{84}$ Thus, the Kitans whose empire's designation was Great Kitan State even seem to have played a role in coining the designation of the Chinggisid state. ${ }^{85}$

We do not know how many of the "new" Mongols were the "old" Kitans and their descendants, perhaps a sizeable amount since the Kitans seem to have numbered millions. ${ }^{86}$ Or perhaps the legitimate question to be asked is how the Kitans were the early Mongols since Mongol was a Kitan division. In fact, Rashid al-Din's report about the Kitans that "They are adjacent to the Mongol nomads, and their language, physiognomy, and customs are quite similar" can be read in a reverse way to say that because the Mongols were under the Kitan Empire, their language, physiognomy, and customs would have been quite similar to those of the Kitans. ${ }^{87}$ In fact, Biran's meticulous documentation of the Mongolization of the Kitans under the Mongol Empire can equally be true of the Mongol divisions of the Kitan Empire, for they were under the dynasty for more than two centuries. ${ }^{88}$ Not only the political order and culture, but also the people were undoubtedly inherited and integrated too. Unfortunately, it is worth noting, the pervasiveness of the conventional "tribalist" or ethnological or even "ethnicist" bottom-up view precludes a fuller appreciation of these transformations, as if these "tribal" or "ethnic" population categories were rock-solid entities and the populations were inherently incapable of integration, enculturation, acculturation, and assimilation, as if they were beasts. ${ }^{89}$ Yet, as Biran critically notes, many

82 Ibid., p. I64.

83 Munkuev I975, pp. 56, 250.

84 Ibid., pp. $65,263$.

85 Kane 2009, pp. I62-65. For the name Kitan also see Róna-Tas 2016.

86 See Biran 20I5, p. I54; Atwood 2004, pp. 3I4-I9; Kane 2009, p. 267. According to Biran 20I5, p. I54, "The Jin Kitans reportedly numbered between 750,000 and I.5 million men”.

87 Rashiduddin I998, p. 2 I4.

88 Biran 20I5. Though Biran concludes that "the Mongols were indeed agents of" the Kitan assimilation, in fact her documentation and arguments abundantly demonstrate that it was, in fact, the state or statecraft, its policies and its institutions of administration and governance such as the army that played a crucial role in the Mongolization of the Kitans.

89 In fact, as early as I824, Nikita Bichurin, criticizing major European scholars such as Julius Klaproth, argued, "Presently, many scholars in Europe engage in investigations of the origins of the peoples that, according to their opinion, dwell or once dwelt in Mongolia. However, knowing no people solidly, nor its history, they make erroneous assumptions in their research ... Almost all the powerful lineages (поколение) are considered as distinct peoples (народъ), distinct from the rest of the lineages by origin and by language. Herein lies their gravest mistake" (Iakinf I828 v. I, pp. I56-67). Bichurin believed that "The whole state (государство) or people (народ) acquired its name from its reigning house (господствуюшаго дома), and each division (aimag or аймак) from its ruling lineage (владительныхъ поколения)" (Iakinf I828 v. 2, p. 2). Thus, Xiongnu, Xianbei, Khitan, Mongol or Chakhar, Khalkha and Kharachin and so on all initially were ruling houses (господствующій дом or владетельный дом) (Iakinf I828 v. I, pp. I57-58; Timkovsky I824, pp. I74-85). When one of the most successful of these ruling houses established its own dynasty, it displaced the others. Mongol was one of the latest and the most successful of these ruling houses. If the ruling house had been the 
authors are keen to highlight what "is often described as 'barbarian' assimilation" of the ruling nomads "into more elaborated sedentary culture" or "the nonautarkic character of nomadic culture", alluding or even claiming the inherent superiority of the sedentary over the nomadic. $9^{\circ}$

That the heads of the pre-Chinggisid Mongolian polities held military or military-oriented titles such as senggüm, lingqu, buyiruq, beki, bahadur or ca'ut-quri or ja'ut quri seems to suggest not only the origin of their divisions but also their subordinate status in relation to a higher authority. ${ }^{\text {I }}$ By the time of Temüjin's birth these divisions were, in all probability, becoming principalities or, perhaps, lordships of various sizes.92 Some of their commanders had claimed the title of khan as Ambaqai, son of a senggüm, and grandson of a lingqu, did. The title "Buyuruq Khan" that we find among Kereyid, Naiman, Tatar, and Bätäkin shows this development as well. 93 As Rashid al-Din tells us that "rulers were entitled ... Buyuruq Khan, .. buyuruq because it means commander", clearly division commanders or buyiruqs were becoming Khans, hence Buyuruq Khan (Commander Khan). ${ }^{94}$

Temüjin himself was a perfect embodiment of this transformation; he was a ca'ut-quri or "commander of a hundred" or "commander of a division" recognized by the Jin dynasty (within the realm), and at the same time a khan to his principality, a division turning into a principality. For this reason, Temüjin, who was effectively overthrown as the khan of the Mongols in the Qalaqaljit Elet battle, was claiming himself as ca'ut-quri to Altan and Quchar, the two remaining princes who elected him as the khan of the Mongols but now had overthrown him with the help of Ong Khan. Thus, Temüjin's message to Altan and Quchar also conveyed that "Even if you two have renounced me as the khan I am still the Jin-bestowed ca'ut-quri, the division commander”. As Susan Reynolds has observed in the case of medieval Europe, administrative divisions of one generation were becoming lordships in later generations. 95

Thus, the collapse of the Great Kitan State left a power vacuum which every power holder, be it the Zubu-Kereyid ruler or other divisional commanders such as Temüjin and his immediate predecessors, rushed to exploit to increase their power. Some, like

house of Kharachin instead of Mongol, the entire population of Mongolia would have been known as Kharachin (Iakinf I828 v. I, pp. I57-58). The entire population of Mongolia became known as the Mongols "not because they descended from the house of the Mongols"; instead the house of the Mongols subjugated the rest of the houses and their domains and built a sort of new state, and the name was imprinted upon its population (Iakinf I 828 v. I, p. I57).

Biran 20I5, p. 5.

Kereyid, Naiman and Tatar rulers held the title of buyuruq, Merkit and Oyirad beki. While others held the title of ba'atur and tekin, Temüjin himself bore the title of ja'ut quri. All of these titles were of a military nature or had military associations, and none was subsequently used as a title for a sovereign ruler.

See Bisson 2009 for lordship and Rashiduddin I998, pp. 37-78 for Rashid al-Din's description of pre-Chinggisid polities.

3 Qurcajuz Buyuruq Khan and Markhuz Buyuruq Khan (Rashiduddin I998, pp. 5I, 62; SHM: §§I4I, I50) of Kereyit, Na'ur Buyuruq Khan of Tatar (Rashiduddin I998, p. 62), Buyuruq Khan of Naiman (Rashiduddin I998, p. 54), naiman-u buyiruq qan (SHM: §I44), (gücügüt-naiman-u buyiruq qan (SHM: §I4I), naiman-u gücügüd-ün buyiruq qan (SHM: §I58), gücügürtei-buyiruq-qan (SHM: §I77), and Qadir Buyuruq Khan of Bätäkin (for Qadir Buyuruq Khan and Bätäkin see Rashiduddin I998, p. 70).

Rashiduddin I998, p. 68. See Clauson I972, p. 387 for buyruk.

Reynolds I997, p. 22 I. 
Ong Khan, Jamuqha, and Temüjin, were assertive in expanding their power at the expense of others, while others were keen to secure their divisions for themselves as their domains. The collapse of the Kitan Empire brought about a state of affairs that the SHM §254 so vividly describes as "the starry sky whirling, the sundry ulus rebelling and plundering sleeplessly, the soily earth overturned, the entire ulus rebelling and pillaging restlessly". In this turbulent state, though everyone was trying to hold on to their power, they were also keen to have order in the realm. While many of these lords were seeking to increase their own power, all of these lords universally held that the "felt-tent ulus" should form a single realm - perhaps an ulus, as it was incarnated in the form of the Mongol ulus later under a single universal ruler, and those who were seeking to increase their powers were, indeed, doing so to become that monarch and to establish order within the realm. ${ }^{96}$ All those who aspired to become the universal monarch vied for the throne of Ong Khan.

This is where the Chinggisid state achieved its takeoff. After the collapse of the Kitan Empire, the Mongol division seems to have emerged as an independent principality under Qabul, the great-grandfather of Temüjin. However, with Qabul's demise the fortunes of the principality seem to have dwindled under the pressure of the Tatars on the one hand, and the Kereyid Kingdom on the other. Eventually, the principality was split into rival divisions, perhaps along its decimal divisional lines, and the last Kereyid ruler, Ong Khan, who had manipulated Mongol nobles to fight with each other for a long time, finally overthrew its last ruler at Qalaqaljit Elet with the help of Jamuqha and Altan, whom he subsequently crushed. The Mongol principality was finished; its khan was overthrown; its population was scattered and its territory was conquered. The triumphant Ong Khan, erecting a Golden Tent, was just about to feast in celebration of his conquest of the Mongol principality, only to be overthrown at that very moment, ironically by Temüjin, whose demise he had been celebrating, and thus gave way to the rise of the Mongol Ulus.

\section{THE CULTURE}

\section{The Idea of a Single Realm and Monarch and the Kereyid Kingdom}

According to the SHM, in I2O I on the bank of the Ergüne River, an assembly of the ruling lords of almost all of the major polities of the Mongolian plateau enthroned Jamuqha as the Universal Khan or Gür Khan (gür-qa[n]) (SHM: §I4I). The Universal Khan declared war on Ong Khan and Temüjin and immediately set out to bring them under his rule. However, his campaign was ill-fated. Not only did the Universal Khan lose the battle, but his forces were scattered, effectively ending his reign. He was "not favored by Heaven" (tenggeri-de ese ta'alaqdaba, SHM: §I43). Yet the Universal Khan's brief enthronement reveals one very important political idea universally held by the aristocracies of the "felt-tent ulus": that there was to be a single universal ruler over all the "felt-tent ulus", meaning that all of the "felt-tent ulus" were to form a single ulus-realm and the parties involved were to form its parts. ${ }^{97}$ Both Ong Khan and Temüjin shared this idea, but Jamuqha was not the

96 See Munkh-Erdene 20 I.

97 In fact, if the idea of a single ulus-realm had not been there, these lords would not have come together to enthrone Jamuqha, and if they had not expected their domains to form parts of that ulus-realm they would not have taken part in the enthronement. Moreover, had they not expected those under Ong Khan 
universal khan for them. Instead, the universal khan and legitimate ruler of the realm was Ong Khan, while Jamuqha appears to have been enthroned to displace him. ${ }^{98}$

When we look at the contemporary political culture it becomes clear that not only was the idea of a single realm of the "felt-tent ulus" well established in pre-Chinggisid Mongolia but also pre-Chinggisid Mongolia formed, though fragmented and decentralized, a single realm under, as the SHM §I87 puts it, "the high throne" (ündür-ün oron) of "Ong Khan, the ancient old Great Khan” (ong-qan erten-ü ötögü yeke qan) (SHM: §I89).99 While Gür Khan's enthronement shows the existence of the idea of a single realm under a single universal ruler, his and other lesser lords' aspiration to the "high throne" of "Ong Khan, the ancient old Great Khan" evidently shows that pre-Chinggisid Mongolia formed a single realm, and that Ong Khan was the ruler of that realm.

While the SHM's lens zooms in on Temüjin's bid for that "high throne" with Jamuqha as his principal rival and Teb-Tenggeri and Qasar as minor obstacles, Rashid al-Din lists Jamuqha, Qasar, Sacha-Beki, and Alag-Udur of Merkit as all being contenders for the rule of the ulus along with Temüjin. ${ }^{\text {roo }}$ However, none of these sources mentions Ong Khan as a contender. This telling evidence suggests that Ong Khan was the de jure sovereign of "Mongolia" whose "high throne" these lesser lords vied for. His son, Nilqa-Senggüm, is not on the above list either, although Rashid al-Din reports him as declaring to Temüjin, "We will do battle, and whichever of us

and Temüjin to be part of that ulus they would not have warred with Ong Khan and Temüjin. Perhaps many envisaged the realm in a different way, but it is very likely that the eventual winner, Temüjin, had envisaged the realm as being forged of tümens ruled by noyans, thus having decimal divisions. Around I I86, long before Temüjin became khan, Qorchi had foretold Temüjin that he would become the "sovereign of the ulus". In response, Temüjin had promised Qorchi that he would make him "noyan of tümen". If that conversation did really happen as the SHM claims, then we cannot but accept that there was an ulus in their minds and that ulus was divided into tümens, or rather they knew it as an ulus divided into tümens ruled by noyans. At any rate, when Temüjin ascended as Chinggis Khan over the "felt-tent ulus" in I 206 after his capture of the Kereyid throne, he did make Qorchi a "noyan of tümen", citing that he had given his word to Qorchi if his prophecy was to be fulfilled (SHM: §§I2I, 207).

98 Munkh-Erdene 20II, p. 227. Historians have long noticed a gap of about ten or so years in Chinggis Khan's life preceding his participation in the I 96 anti-Tatar Jin campaign and following his defeat at Dalan Balzhut at the hands of Jamuqha. The Song envoy Zhao Hong actually claimed that Temüjin spent ten years as a slave in the Jin dynasty (Munkuev I975, p. 49). Ratchnevsky thought that Temüjin was under the Jin authority (Ratchnevsky I99I, pp. 49-50). In fact, according to SHM §I34, the Jin commander Ongging-cinsang (Wanyen Xiang) gave the title of ja'ut-quri or ca'ut-quri to Temüjin for his service in the anti-Tatar campaign. Interestingly, in giving the title, Ongging-cinsang said to Temüjin, "Let Altan Khan know if a greater title than this, the title of jeutau would be given to Chinggis Khan”. Perhaps Temüjin aspired to this title, but what it does prove, however, is that Temüjin was serving under the Jin jeutau or Zhaotao (Frontier/Pacification Commissioner). Thus, after Dalan Balzhut, Temüjin seems to have sought refuge in Jin territory. On the other hand, Jamuqha must have capitalized on his Dalan Balzhut victory and played a role in driving Ong Khan out to Qara Khitai. Thus, I20I is perhaps not Jamuqha's enthronement year as Gür Khan but rather his dethronement (Munkh-Erdene 20II, p. 227).

"ong-qan erten-ü ötögü yeke qan büle'e" (Ong Khan is ancient old great khan) or "ötögü yeke erten-ü ong-qan" (The old great ancient Ong Khan) (SHM: §I89).

Ioo Rashiduddin I998, p. I8I. It is not that the SHM was intentionally distorting its story here. Instead, it is an intrinsic bias generated by the vantage point and its hero Temüjin. Temüjin started his career aspiring to become the khan of the Mongols, a minor principality or division, and Jamuqha's rivalry with him started there. Thus the Chinggisid authors lack the realm-wide or "bird's eye view" that Ong Khanid authors would have commanded. See also Rachewiltz (SHM: §§I2I, 244) for Jamuqha and Qasar respectively. Alag Udur does not appear in the SHM at all. 
emerges will be the khan". ${ }^{\text {Iоr }}$ Nilqa-Senggüm as the crown prince was also not a contender for "the high throne" but its legitimate heir. If Ong Khan and Nilqa-Senggüm had not been either the legitimate ruler or his heir apparent, they would have headed the list of the aspirants for "the high throne". Thus, the Kereyid throne was "the high throne" of the realm, and this was the reason why all these lesser lords aspired to it.

Moreover, Tayang Khan's exclamation "How can there be two khans on Earth?" only presupposes a single, overarching ruler but also reveals his intention to become that ruler. His denouncement of Temüjin for usurping Ong Khan's throne "to become the khan himself" assumes that Ong Khan was that overarching ruler. ${ }^{103}$ No contemporary ruler of the "felt-tent ulus", other than the ill-fated Gür Khan, had held a more senior title than Ong Khan, and while Ong Khan's deposed predecessor held the title of Gür Khan, his heir apparent was called "Sangun, which means prince in the Cathaian language". ${ }^{04}$ The highest title that Tayang Khan held was Tai Wang meaning "khan's son" or prince. ${ }^{105}$ The singularity of the title of Wang or King, with its meaning of "ruler of kingdom or country" that Toghril had inherited and that the Jin dynasty also had confirmed clearly indicates that Ong Khan was the monarch of the realm. ${ }^{106}$ This is the reason why SHM declares that "Ong Khan is the ancient old Great Khan" and describes his throne as "the high throne".

Hence, the universally shared belief that "felt-tent ulus" was to form a single ulus-realm under a single universal monarch on the one hand, and the universal aspirations of those lesser lords to claim the throne of Ong Khan on the other, shows that the single realm was not just an abstract idea; rather, it was substantiated by the Kereyid kingdom and its hegemony over the "felt-tent ulus". We cannot ignore the telling absence of Ong Khan and his son among the aspirants to the throne, and the statements such as that of Tayang Khan that assumed Ong Khan as the khan, and the singularity of the title of Ong Khan and its meaning. All of these suggest that Ong Khan was not just a senior and singular title, instead he really was the "Great Khan" and the monarch of the realm and his throne was "the high throne" of the realm. Thus, the idea of the bounded, limited ulus was likewise not just an abstract idea; the Zubu-Kereyid Kingdom and its hegemony over the former Kitan divisions-principalities embodied it, and indeed, pre-Chinggisid Mongolia had formed a single realm under the throne of Ong Khan.

However, this was a fragmented and decentralized realm plagued by the divisive Kitan legacy and the Jin, Qara-Khitai, and Xi-Xia intrigues, ${ }^{\text {I07 }}$ and Ong Khan, as "the Great Khan”,

I0I Rashiduddin I998, p. I90.

I02 Rashid al-Din has it as 'On the earth how can there be two monarchs in one Kingdom?' (Rashiduddin I998, p. 2OI).

I03 “ötögü yeke erten-ü ong-qan-ni qor-iyar-iyan ayu'ulju ükü'ülba edö'e mün qan bolsu ke'en aqun-u ... qajar de'ere qoyar qat ker bolqu” (SHM: §I89).

I04 Rashiduddin I998, p. I75.

I05 Ibid., p. 69.

I06 Ibid., p. I65; SHM: §I34.

I07 After the Liao, the Jin, Xi-Xia, and Qara Khitai continued to have a divisive influence on Mongolia. Understandably, both of these powers exercised greater influence on their immediate neighbors - the Jin on the Tatar and Qara Khitai on the Naiman - and, in many cases, used them to frustrate the growing power of the Kereyid or Zubu. Thus we have the Tatar warring with the Kereyid and its Mongol subordinates, 
was trying to consolidate his realm while many rival lesser lords such as Temüjin were seeking to replace him. Thus Jamuqha had been enthroned as the Universal Khan to dethrone Ong Khan and thus had warred with him. In fact, all those who had aspired to become the universal monarch had vied for the throne of Ong Khan until Temüjin claimed it by deposing Ong Khan. Thus, the Chinggisid state was not only an embodiment of the idea of a single ulus-realm but also was built upon the Kereyid Kingdom. ${ }^{\text {108 }}$

\section{"Ascending the High Throne": Legitimacy and Sovereignty}

As our story demonstrates, Temüjin did not just claim or usurp "the high throne", instead, he "ascended the high throne by the favor of Eternal Heaven" because Ong Khan had "lost the favor of Heaven" by severing himself from törü. ${ }^{\text {Io9 }}$ In other words, Temüjin ascended "the high throne” legitimately when Ong Khan lost his legitimacy. Temüjin's night assault was legitimate, and his deposing Ong Khan was legitimate. This is the entire reason for our story being in the SHM, and the entire reason that the SHM took pains to elaborate on this story in detail, as well as our reason for examining this story. Our contention is to explicate the significance of this story in order to do justice to pre-modern Inner Asian political culture. Furthermore, our story claims that Ong Khan not only admitted that he himself had lost his legitimacy but also that of his heir apparent, Nilqa-Senggüm, the crown prince, which even justified the transfer of "the high throne" or sovereignty to rule the realm to Temüjin.

In responding to Temüjin's grievances, a remorseful Ong Khan is said to have confessed, “'O punish me! I have chopped a deed that shouldn't be chopped [and] have severed myself from törö, severing myself from my son"”. ${ }^{\text {I }}$ " “Now, If I plot evil against my son [Temüjin] again, my blood should be shed like this!' he vowed, pricking the flesh of his little finger with a whittling knife to draw blood, [and] putting it in a little [capsule] with a top" and sending it to Temüjin (SHM: §I78). Thus, Ong Khan unequivocally confessed that he had done a deed that he should have never done, and he had severed himself from törü by severing his relationship with Temüjin, and hence he must be punished. Moreover, Ong Khan for all intents and purposes not only sentenced himself to death by declaring "my blood be shed like this" but also handed the sentence over to Temüjin for execution by sending his blood to him.

Ong Khan's response can be read as a Chinggisid fabrication, or rather, a Chinggisid conviction of Ong Khan. Indeed, later Chinggisids dropped the "death penalty". Instead, as Rashid al-Din reports, Ong Khan responded saying, "He is right. He has been dealt with unjustly, but my son Sangun knows how to reply". ${ }^{\text {II }}$ However, it is plausible that Ong Khan really did send Temüjin his "death penalty", not with regret and confession

and we see the Naiman forcing Ong Khan to flee. Xi Xia was also involved in Mongolia's politics as it gave the title jagambu (commander of a province) to a Kereyid prince (Rashiduddin I998, p. 64).

Io8 Munkh-Erdene 20II, 2016.

Iо9 “möngke tenggeri-de ihe’ekdejü kereyit irge doraida'ulju ündür-ün oron-tur gürba-je” (SHM: § I87).

I Io "ai soyuliq kö'ün-ece-'en qaqacaqu-yü törö-dece qaqacaba hirijegü-yü üyile-dece hiriceba bi” (SHM: § I78). Here, soyuluq is clearly another declarative form of the verb süyitügei, süyütügei, or söyütügei.

I I Rashiduddin I998, p. I90. 
but instead with disdain and mockery. After all Ong Khan was "the Great Khan" while Temüjin was “a stray on horseback”. Hence, a fugitive's demand of war reparation from "the Great Khan" must certainly have incited mockery and disdain (dura alja'at). Surely, Ong Khan, who spat in the faces of his brothers and commanders simply for silly backbiting, and forced many others to do the same, must have despised Temüjin for his lese majesty, and might have mocked him saying "Over my dead body!” (SHM §I52).

As for the crown prince, the angered and ashamed Nilqa-Senggüm is said to have declared, "The tricks in these words have been understood, [they] are words commencing war. Bilge-Beki and Tödö'en, raise the war standard, fatten the geldings” (SHM: §I8I). Rashid al-Din goes further to claim that Nilqa-Senggüm challenged Temüjin to battle, declaring, "We will do battle, and whichever of us emerges will be khan". ${ }^{\text {I } 2 ~ H e ~ e v e n ~}$ elaborates on this, saying that Nilqa-Senggüm had declared, "We shall do battle. If he is victorious, our people will be his. If we are victorious, his people will be ours". ${ }^{113}$ Whether from shame or disdain, Nilqa-Senggüm's reaction is more likely the answer that Temüjin's grievances and demand for war reparation must have generated. ${ }^{\text {II } 4}$ Thus both "the Great Khan" and his successor challenged Temüjin, and their stake was "the high throne": the sovereignty. Clearly, Temüjin must have expected precisely such a response. In fact, in opening his message to Ong Khan with the phrase "our geldings have fattened" (aqtas manu üyeleba), Temüjin was declaring war on Ong Khan. Thus, Nilqa-Senggüm's "raise the war standard, fatten the geldings" was precisely the response that Temüjin's declaration of war would have generated. ${ }^{\text {II } 5}$ Thus, in sending his message to Ong Khan, Temüjin was not just announcing his legitimate grievances and demanding war reparations, rather he was declaring war on Ong Khan, substantiating it with his legitimate grievances and demand for war reparations. And his war reparation was to be Ong Khan's "mockery" and Nilqa-Senggüm's bet, "the high throne", the sovereignty to rule the ulus. Thus, Temüjin's usurpation of Ong Khan's throne was legitimated; Ong Khan severed himself from törü ${ }^{I 6}$ and lost heaven's favor. His response earned him the death penalty, and handed this over to Temüjin for execution, though Qori-Sübechi's intervention saved Temüjin from regicide. As for the crown prince, Temüjin gave him the battle that he wanted and came out victorious. Thus Temüjin was legitimately entitled to take "the high throne"; the transfer of sovereignty to rule the realm was just. So the Chinggisids rationalized the event ex post facto.

\footnotetext{
II2 Rashiduddin I998, p. I90.
}

I 3 Ibid. The irony is that, as Achiq-Shirun had already declared, there was no ulus with Temüjin to take; he was reduced to "a stray on horseback" and his ulus was already under Ong Khan with Jamuqha, Altan and Quchar.

I 4 Rashid al Din has this: "[Ilqa-Senggum] ordered his two great commanders Bilga Beki and Todo'an, saying, 'We mount with the army. Raise the standards, sound the drums, bring in the steeds for us to mount, and let us set forth against Genghis Khan!” (Rashiduddin I998, p. I90).

I 5 Waging war was dependent on the condition of geldings and the SHM abundantly documents the importance of horses in this regard. For instance, in the SHM§§ I90, I93, I94, both Chinggis Khan and Tayang Khan of Naiman carefully deliberate on the conditions of their geldings when deciding whether to begin the war or to postpone, and how to wage the war in accordance with whether their geldings were fat or lean. Fat geldings meant readiness for war, while lean meant the opposite.

II6 In the $S H M \S \S I 78,208,263,28$, törü is spelled as törö, töre, and dörö. 
Though there is no explicit reason to doubt this, we do not know if Temüjin really did send the messages to Ong Khan and his allies, and if Ong Khan and Nilqa-Senggüm really did respond the way they are depicted as having done in the Chinggisid accounts. Perhaps we will never know. However, we do know that the Chinggisid authors took great pains to meticulously belabor all these points. Thus, we can be sure that there was a political culture that held that rulers and their actions should concur with törü and should be favored by heaven. Actions such as attacking without pretext or justification, and attacking without declaration of war, and reneging on one's promise, and betraying one's ally, and attacking one's ally against an alliance treaty were all "actions that should not be done" because they contravened the accepted norms of the day and were liable to penalty or punishment. Most importantly, such actions of rulers like Ong Khan were an act of severing oneself from törü and, as Ong Khan repeatedly declaimed, rulers who committed such actions were to be "not favored by Heaven", hence would lose their legitimacy. Moreover, as both Ong Khan's mockery and Nilqa-Senggüm's bet - that is, the stipulation of the war result shows the transfer of sovereignty to be just.

Yet, still it took Temüjin to bring all the "felt-tent ulus" or "Mongolic ulus" under his rule and a yeke qurilta or a great assembly for him to be enthroned as the khan, or as the SHM $\S 202$ puts it, to be "given the name of qan" (qan nere tende ökba), which happened three years later in the year of the Tiger (I206) at the source of the Onon River. The Great Assembly raised a nine-legged White Standard and enthroned Temüjin as Chinggis Khan, while his new ulus was named Mongqol Ulus or Yeke Mongqol Ulus (SHM: §202). ${ }^{\mathrm{I} 7}$ Thus, though Temüjin's claiming "the high throne" or sovereignty was legitimate and just, he was still to be invested with the title of khan and enthroned, as well as enthroned by the Great Assembly, and his polity was to be properly designated, that is, formally legitimating, authorizing and legalizing the sovereignty and "establishing the state" (ulus bayi'ululcan). This is the significance of the institution of declaration or formalization that involved the institutions of investing with the title, and of enthronement, and of the enthroning institution of the yeke qurilta as well as the designation of the ulus or the political formation. For this reason, the enthronement of a new khan as well as the enthroning institution of yeke qurilta was crucial during the Mongol Empire.

In fact, in the Chinggisid accounts Chinggis Khan emerges as the monarch who "upheld

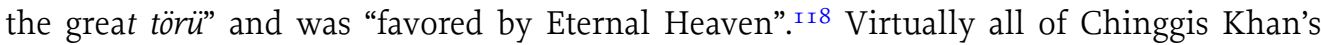
wars had just causes or pretexts. ${ }^{\text {I9 }}$ Furthermore, as Temüjin’s denouncement of Ong

I 7 See Hodous 2012/2013 for quriltai.

I I8 "yeke töre setkijü”, "törö setkijü” or "yeke törö-yi setkijü’üi” and "möngke tenggeri-de ihe’ekdejü" (SHM §§208, 220, I87, 203, 256, 265).

II9 Xi Xia (I038-I 227) provoked his last campaign not only by breaching its treaty obligation but also insulting and inciting him to war (SHM §§256, 265). He invaded both the Jin dynasty (I I I5-I 234) and Khwarazm-Shah (I077-I23I) for having executed his elchin (ambassadors or envoys) that he saw as his "golden tether" (altan arqamji) (SHM §§25I, 254, 256). Rashid al-Din, even, elaborates, "Even though the sultan had initiated the strife, ... Genghis Khan did not want to attack him and sought in every way possible to tread the path of amity and neighborliness. In fact, he did not move to do battle with the sultan until the latter had taken several insulting and hurtful actions that called for revenge. The first was that he thoughtlessly and unforesightedly killed the group of merchants and ambassadors [Genghis Khan] had sent to seek friendship and peace with friendly messages, paying absolutely no attention to what they had to say. Second was that he fought with his soldiers when they were unwilling. Third was that the sultan usurped entirely all the lands in 
Khan attacking him without prior declaration of war shows, it was the norm to declare war on one's enemy in advance of commencing hostilities. Indeed, while the SHM §265 tells us how Chinggis Khan made a declaration to Xi Xia to prepare for battle, both Juvaini and Rashid al-din claim that "envoys were sent to the sultan to remind him of the treachery that had issued from him without justification and instructing him to prepare himself for battle with the army that was moving in his direction". ${ }^{20}$

In fact, it is not only Chinggis Khan who declared war on his adversaries; his adversaries also declared war on him too, though the Chinggisid sources do not explicitly say so. Temüjin was informed about impending war against him at least twice in the SHM $\S \S I 29$, I4I. Once before the battle of Dalan Balzhut, Temüjin was informed about Jamuqha's advancing forces by Mülke Totaq and Boroldai of Ikeres ahead of time so that he could regroup his forces and march against Jamuqha to engage him at Dalan Balzhut ( $S H M$ § I29). Then, he was informed by Qoridai of Qorolas of the impending advancement of the Gür Khan against himself and Ong Khan way ahead of time so that Temüjin and Ong Khan could join forces and march against Jamuqha, the Gür Khan, over a great distance to Köyiten, where the adversaries did battle. However, the SHM only reports that Mülke Totaq and Boroldai of Ikeres, and Qoridai of Qorolas "came delivering the news" (kelen gürgen irejü'üi). On both occasions, those who delivered the news came from the side of Temüjin's adversaries. However, the SHM does not say if they were dispatched by Jamuqha or if they came on their own.

Yet there was no doubting whatsoever or "believing in their words" on Temüjin's part as he did "believe in Badai and Kishiliq's words" (badai kis[i]liq qoyar-un üges büsirejü) (SHM $\S$ I69). Thus, the news that Mülke Totaq and Boroldai, and Qoridai respectively brought needed no verification. Their news was certain. Nor there was any gratitude or rewarding on the part of Temüjin as he had displayed with Badai and Kishiliq (SHM §I87, see note I 25 below). It is true that Rashid al-Din on two separate occasions reports that Qoridai was sent by Märkitäi, a Qorolas officer, but he does not mention any return appreciation or reward from Temüjin either to Qoridai or to Märkitäi. ${ }^{\text {I2 }}$ Thus, clearly, they were messengers that brought Jamuqha's declaration of war to Temüjin. Moreover at Köyiten, as well as at Baidaraq-belcir before Ong Khan's Kögse'ü-Sabraq incident, the approaching advance forces (manglai) of the adversaries communicated with each other and agreed to do battle the next day (SHM §§I42, I59). ${ }^{\text {I22 }}$

To be sure, violations of these norms did occur, yet when they did, they incurred similar retaliation. The Merkit abduction of Börte-Üjin seems to have been one such violation - a retaliation for Yisügei's earlier capture of Ö'elün - that provoked the joint onslaught of Ong Khan, Jamuqha and Temüjin against the Merkits as Temüjin complained to Ong Khan that the Merkits had attacked him unawares (genen) (SHM §98-I I I). ${ }^{23}$ Surely, the onslaught of

Turkistan that had been held by Gu shlüg after he was killed by Genghis Khan's soldiers. Altogether these things caused a vengefulness and enmity and created a desire for redress and expiation" (Rashiduddin I998, pp. 236).

I20 Rashiduddin I998, p. 235; Juvaini I997, p. 8I.

I 2 I Rashiduddin I998, pp. 88, I82.

I 22 On both occasions, SHM §§I42, I59 uses an identical expression jilda boldaju manaqar qatqulduya.

I23 “qurban merkit-te genen büküi-tür irejü eme kö’ü-ben dauliju a[b]daba” (SHM §IO4). 
Ong Khan and his allies on Temüjin was meant to be such a "surprise siege and capture" (bücijü bariya). ${ }^{\mathrm{I} 4}$ Only Badai and Kishiliq's intervention narrowly saved Temüjin from certain death. ${ }^{\mathrm{I} 25}$ In response, Temüjin, though he had already declared his grievances and hostility, employed exactly the same "surprise siege" method against Ong Khan at the mouth of Jeje'er Ündür's Gorge. ${ }^{\text {I26 }}$

Even if we approach the SHM in a most cynical way and treat it as a Chinggisid hypocrisy aimed at legitimizing Chinggisid rule, the fact remains that the SHM goes to great lengths to meticulously elaborate all these details to make its audience believe that Temüjin's usurpation of Ong Khan's throne was legitimate and that Chinggis Khan was the ruler who "upheld the great törü" and was "favored by Eternal Heaven".

In this view, the SHM speaks to us a great deal about the political culture that existed among the ruling elites of the Mongolian plateau at the time. If there had been no such political culture the Chinggisid authors would not have labored to make Temüjin's usurpation of Ong Khan's throne seem legitimate. If there had not been such a political culture the $S H M$ would not have labored to meticulously elaborate Chinggis Khan as the ruler who "upheld the great törü" and was "favored by Eternal Heaven", that is, the legitimate ruler. Furthermore, even if Chinggis Khan had not been the ruler he is depicted as being in the SHM, it is certain that there was a culture to forge this hypocrisy, a political culture that was built on hierarchy and order that valued justice, legitimacy, integrity, fidelity, righteousness and virtue. In this sense, the SHM, to invoke Alasdair MacIntyre, "Provides a moral background to contemporary debate" in medieval Inner Asian society, and it is "an account of a moral order whose beliefs and concepts were still partially influential", even though the society was not actually what MacIntyre calls a "heroic society". ${ }^{\text {I27 }}$

The SHM as an account is a moral tour de force: it commends, through the words of Chinggis Khan, numerous virtues of the actors, including many of his adversaries. From among his adversaries, the SHM (§§I47, I49, I85, I97) commends Jebe for his honesty and bravery, Naya'a and Qadaq-Ba'adur for their fidelity, while $\S \S 188,200$ condemn Kököchü and Jamugha's entourage for their infidelity, even though they rendered great services to Temüjin. On numerous occasions, SHM even commends his archrival Jamuqha for his chivalrous deeds ( $S H M$ §§ I05, I08, I I7, I 70, I96, 20I). Yet it never explicitly commends Chinggis Khan as being virtuous; instead it shows him in his actions - "in his actions" performed in particular situations, in what he did and said and suffered - the man's virtues and vices are on display. ${ }^{128}$ Unlike the later Chinggisid sources, the SHM does not shy away from showing or chastizing Temüjin's vices, such as his killing of his half-brother, Bekter, his abandonment of his wife, Börte-Üjin, his maltreatment of Büri-Bökö, his distrust

I24 “bid managar ert bücijü bariya” (SHM §I68, I69).

I 25 Badai and Kishiliq, two horse herders ( $\left.a d u^{\prime} u c i\right)$, warned Temüjin of Ong Khan’s surprise attack (SHM §I69). Temüjin rewarded Badai and Kishiliq with "Ong Khan's golden tent just as it stands, with his golden bowls and vessels together with the people who looked after them, and the Ongqojit Kereyid as their bodyguards" and made them darqan (SHM §I87, see Atwood 2004, p. I33 for darqan).

I 26 "qali'udar caqurqan qoyar cinggis-qahan-a ügülerün ong-qan genet bui ... sönit dülil[i]gejü nenden büciye ke'eba ene üge-yi jöbsiyejü ... büciba” (SHM §I85).

I 27 MacIntyre 2007, pp. I2I-30.

I 28 MacIntyre 2007, p. I22. 
and mistreatment of his brother, Qasar, and even his sons on the Urgench occasion ( $\$ \S 77$, 78, 99, I00, I83, 244, 260). If, as MacIntryre claims, "Morality and social structure are in fact one and the same in heroic society", ${ }^{29}$ the story and the messages discussed at length in this article are evidence of that culture and society, and the törü that Ong Khan repented of having severed himself from is one of the most fundamental concepts in the understanding of pre-modern Inner Asian political culture.

\section{Törü: A Moral Regime}

As our story shows, a ruler contravened or violated törü at the risk of losing his mandate of heaven. For rulers, törü was the thing that they had to claim that they followed, supported and upheld, and their actions had to accord with it. Or, at least, törü was the thing that rulers invoked to justify their actions. Indeed, while "the mandate of Eternal Heaven" was the source to which the khans attributed their fortune and sovereignty, törü was the thing against which their legitimacy, righteousness, virtue and actions were judged. Thus, all these rulers appear to have been operating within the regime of törü under the watchful gaze of heaven.

So, what was törü, or more specifically, what was the törü that Ong Khan lamented he had severed himself from? Törü is an enduring concept in Inner Asian political culture and is attested first in the Orkhon inscriptions. It has been read variously as norm, principle, custom, manner, law, government, and the state. ${ }^{\mathrm{I} 30}$ In modern Mongolian, it is chiefly associated with government and the state, yet still with all the connotations mentioned above. Though it is abundant in the extant sources of the thirteenth and fourteenth centuries, there have been very few attempts to tackle it. ${ }^{\text {I3I }}$ Though törü deserves further investigation, here I will examine its occurrences in the extant Mongolian sources of the period, to explicate what Ong Khan meant when he lamented that he had severed himself from the törü in particular, and more generally to show its significance in the contemporary political order and culture.

Though rulers were the most heavily scrutinized actors of törü, törü was much more inclusive. There was törü for everything or everything had its own törü: from land and water to Bodhisattvas and Devils, from khans and ministers to cattle and hens; each had its own törü. ${ }^{132}$ There was also törü of dharma and a törü of Mahayana. ${ }^{\text {I33 }}$ There were törü to respect, törü to care, and törü to mourn. ${ }^{134}$ There were also lust (taciaqui), discontent/disgust (duran qutaqui), lechery (quricaqui), fear (ayuqui), indolence (umtaraqui), doubt (tegüdesiyeküi), anger (kilingleküi), renege or breach of promise (bucaqui), seeking of booty or profit (olja eriküi), vanity or self-aggrandizement (öber-iyen maqtaju), humiliating others (busud-i doromjilaqui), and debasing others (maqui dor unaqaqui); all these were the törü of

\footnotetext{
I 29 Ibid.

I30 Tekin I968.

I3 I See Humphrey and Hürelbaatar 2006; Munkh-Erdene 20Io, Skrynnikova 20I3, pp. 54-59.

I32 Tumurtogoo 2006, pp. II2, II3, I29, 250.

I33 “Nom-un törü" and "yeke kölgen-ü törü" (Tumurtogoo 2006, p. 8I).

I34 Tumurtogoo 2006, pp. 6I, 64, 75.
} 
Simnu or the Devil. ${ }^{35}$ On the other hand, teaching and educating one's subjects were also the khan's törü̈. ${ }^{36}$ Everything had törü for its existence, and each and every one had törü in their manner and conduct. As there was "törü to ultimately disperse those who gathered together”, there was törü for occurrence or happening. ${ }^{137}$ In short, everything had törü and every occurrence and every action and conduct had törü or was governed by törü.

Communities or entities had their own törü or were governed by it. For instance, there was a Mongolian törü according to which there was a custom or norm (yosun) to make a lord (noyan) a beki, and accordingly Chinggis Khan made Usun, an elder, the beki (SHM §2I6). There was also "yosu törö" or "törö yosun" of a city or settlement. Chinggis Khan appointed Yalawachi and his son Masqud as assistants to governors (daruqachas) of Zhongdu (jungdu-balaqasu) in China, and Bukhara, Samarkand, Urgench (buqar, semisgen, ürünggenci) and other such cities because they knew "city yosu dörö" (balaqasun-u yosu dörö) or "city törö yosun" (balaqasun-u törö yosun) (SHM §263).

Törü is given. It emanates from heaven and earth. For instance, the joint will of heaven and earth that commanded that "Temüjin become the sovereign of the ulus" was a törü. ${ }^{\text {I38 }}$ Thus, törü appears as if it is above and beyond any worldly authority including the khan. Yet, törü also derives from something human or worldly. "While for a father to care for his son was heavenly destiny, the törü of the harmony of the khan and his subjects (qarachu) was derived from it. ${ }^{139}$ "Ancient sage khans comprehended the törü of worshipping the tenggeri from the törü of caring for their fathers", as well as "the törü of worshipping Mother Earth (ötegen eke) from the törü of caring for their mothers”. ${ }^{\text {140 }}$ Thus törü appears human or worldly, yet something that is given or natural.

Törü governs. It is normative, that is, everyone, including the khan, was to uphold and follow the törü. Righteous and virtuous conduct is always commended as conforming to or upholding "the great törü". ${ }^{\mathrm{I} 4 \mathrm{I}}$ "Those who follow törü yosu earn a good reputation”. ${ }^{\mathrm{4} 2}$ On the contrary, if someone neglects or contravenes törü, that one is scolded and frowned upon. For instance, "Coercing the khan is the same as ignoring His Highness (dege:düs) as non-existent, scolding Holy Ministers (Boqda sayi:d) is the same as ignoring the jasaq törü as non-existent, and scolding the törü of care (taqamdaqu törü, filial piety) is the same as ignoring one's father and mother as nothing". I43 Likewise, "One that respects

I35 Poppe I967, pp. 49, I4I.

I36 Ibid., pp. 65, Cleaves 200I, pp. I4, I7. "boqdas qad ede soyüger uqaju irgen orqon-i surqaquldaqu törö ajuqu" (Cleaves 200I, p. I4).

I37 Cleaves 200I, p. I20.

I38 The SHM §I2 I tells us a story of how a shaman (ja'arin) revealed to Qorchi that the will of Heaven and Earth came together and said that "Temüjin shall become the sovereign of the ulus"; Qorchi refers to this as törö.

I39 Cleaves 200I, pp. 80-8I; Tumurtogoo 2006, p. 68.

I40 Tumurtogoo 2006, p. 73; Cleaves and Rachewiltz 2007, pp. I52-53.

I4I Tumurtogoo 2006, p. 29; SHM §220.

I42 “törü yosuqa:r yabun sayi:n ner-e qoyi:dus-a aldarsiqu:luqa:d” (Tumurtogoo 2006, p. 6r; Cleaves I982, p. 72).

I43 Tumurtogoo 2006, p. 68; Cleaves and Rachewiltz 2006, p. 399. “Qan kümü:n-i šiqan aburilaba:su dege:düs-iye:n ügei-e toqa:qsan-dur adali ... Boqda sayi:d-i buruqu:siya:ba:su jasaq törü-yi ügei-e toga:gsan dur adili ... Taqamdaqu törü-yi buru:siyaba:su ecige eke-yügen yaqun-a ba es-e toqa:qsan-dur adali” (Tumurtogoo 2006, p. 70). 
strangers without respecting one's own father and mother is an alien (jočin) to törö". ${ }^{44}$ Khans were to rule "the people of the world by törü and yosu" while ministers, and generals "serve for the great törü". ${ }^{\text {I45 }}$

Though törü is normative, unlike jasaq it has no prescribed or legal penalty or punishment. In the sources of the period, törü appears in combination with yosu and jasaq as törü yosun or törü jasaq and on some occasions, yosu is used as if it were a synonym of törü. However, there are critical differences between them. Törü is always normative, that is, everyone was to uphold the törü, while yosu is not necessarily or not always normative; rather yosu is the way things are or way things occur. On the other hand, jasaq always has a prescribed penalty or punishment. Most importantly, as there was a "yosu to make a noyan a beki, in Mongolian törö" yosu and jasaq derive from törü (SHM §2I6). ${ }^{\text {I46 }}$ Moreover, jarlig or 'decree' derives or is founded on or legitimated by törü. For instance, Chinggis Khan, "in accordance with great törü" rewarded those who rendered "help to assemble the separated ulus, and to collect the scattered ulus" and issued a jarlig so that "my descendants (minu uruq) who succeed our throne (bidan-u oro sa'uju)" reward those who "rendered similar help (tusa) in accordance with töre without violating my words (üge) for generations to come" (SHM §208). ${ }^{147}$

In this sense, törü appears to be an all-embracing, given, governing and normative - yet different from legal regulations - regime or order, a normative constitution or regime that governs everything: a moral regime. In this sense, the concept of törü appears very similar to the concept of dharma and dao and for that matter it is similar to the European idea of natural law. Indeed, in a Mongolian version of Subhasitaratnanidhi, dharma is rendered as törü of the book. ${ }^{\mathrm{I} 48}$ Meantime, in a Mongolian version of the Hsiao ching, törü is rendered as Chinese dao 道, törü yosun as Chinese yao-tao 要道, and jasaq törü as Chinese $d u$ 度 and $f a$ 法. ${ }^{4} 49$

Hence törü was the humanly, naturally or heavenly-established moral regime. As such it was not only the source of order, norms, custom or tradition (yosu), law (jasaq), decree ( jarliq), and government but also the constitution against which every conduct and government was judged. Of all the actors, khan is the most important in the sources. Khans were to rule "the people of the world by törü and yosu" and, indeed, "Ancient sage khans governed the people of the world by the törü of care". ${ }^{150}$ "Nothing but to conduct oneself in accordance with törü was the best way to govern their subjects". ${ }^{\text {I5I }}$ Thus rulership or

I44 Cleaves 200I, pp. 8I, 86; Tumurtogoo 2006, p. 68. “ečige eke-yügen ülü kündülün jad kümün-i kündülebesü törö-dür jocin kemegdeyü" (Cleaves 200I, p. 8I).

I45 Tumurtogoo 2006, p. 6o, Cleaves I982, p. 72. “yeke törü-yi:n emüne kücü öggün” (Tumurtogoo 2006, p. 29).

I46 “mongqol-un törö noyan mör beki bolqui yosun aju’ui” (SHM §2 I6).

I47 "yeke töre setkijü ... qaqacaqsan ulus qamtutqaqsan-u butaraqsan ulus bügütgeldüksen tusas-un inu törö setkijü ... mono qoyina minu uruq bidan-u oro sa'uju ene metü tusa kiksen töre setkijü minu üge busi ülü bolqan uruq-un uruq-a gürtele ... bu tasultuqai ke'en jarliq bolba" (SHM §208).

I48 Bosson I969, p. I72. An old Turkic Buddhist sutra called Säkiz Yükmäk Yaruq found among the Turfan texts translates Buddhist dharma (rendered in Chinese as dao 道) as törü along with nom (Mongolian book or scripture) (Oda 20I5, pp. I62-63).

I49 Cleaves I992, pp. I39, I4I, I47; Cleaves I982, pp. 72, 73, 78; Cleaves I99I, pp. I24, I26, I30.

I50 Tumurtogoo 2006, pp. 60, 66; Cleaves I982, pp. 72-73.

I5I Tumurtogoo 2006, p. 70; Cleaves and Rachewiltz 2006, pp. 40I-2. 
government was to be bound by törü. Indeed, because there was Mongolian törü, Chinggis Khan made Usun, an elder, the beki; and because there was "city yosu dörö" or "city törö yosun", Chinggis Khan appointed Yalawachi and his son Masqud as assistants to the governors of Zhongdu, and Bukhara, Samarkand, Urgench and so on. Furthermore, because there was a törü not to betray one's sovereign, Chinggis Khan commended Naya'a, who released his sovereign Tarqutai-Kiriltug, Temüjin's opponent, as "upholding the great törü (yeke törö-yi setkijü'üi) and entrusted him with the administration of his central tümen (tüb-ün tümen)" (SHM §220). Thus, a sovereign was to rule in accordance with the törü. In this view, the khan was to be the most virtuous moral actor.

Clearly, this was the reason why the SHM and the other Chinggisid accounts made such efforts to depict Chinggis Khan's actions as just and virtuous. ${ }^{152}$ The order established by törü was a moral order. To invoke Durkheim, törü was "the organ of social justice. Through it [was] organized the moral life of the country". ${ }^{53}$ Precisely because törü governed everything and because everything had its own törü and also because there was a törü to declare one’s grievances, a törü to honor "Yes" or a treaty, a törü to declare war, a törü to demand war reparations, a törü to "ascend the high throne", a törü to invest with a title, a törü to enthrone the ruler, a törü to be enthroned by yeke qurilta, a törü to convene a yeke qurilta, a törü to designate the ulus, and a törü to establish ulus, these things happened the way they happened or were rationalized in accordance with törü. Thus, making a sovereign and establishing an ulus was not at all "institutionalizing' charismatic authority in the form of permanent offices, laws, and traditions" and making a community of "charismatic disciples" or "a temporary political association built around the charismatic leadership of an individual to a permanent government supported by laws and traditions". ${ }^{54}$ On the contrary, it was "enthroning the khan in accordance with the törü", (norms, customs and traditions) and "establishing the ulus in accordance with the törü" (norms, customs, and traditions and laws) of the community, that is, both the political authority and the political community were built on the törü (norms, customs, and traditions and laws) of the political authority and the törü of the community.

Indeed, while John of Plano Carpini admires the moral integrity of the Mongols, Friar William of Rubruck tells us that he was scolded by Möngke Khan, who said, "We Mongols believe that there is but one God by Whom we live and by Whom we die, and towards Him we have an upright heart ... To you God has given the Scriptures and you Christians do not observe them ... you do not keep them; to us, on the other hand, He has given soothsayers, ${ }^{155}$ and we do what they tell us, and live in peace". ${ }^{56}$ That "'one God' is, of course", as the late Igor de Rachewiltz put it, "Heaven [or tenggeri] - the 'maker of all things' and master of one's destiny ('by Whom we live and by Whom we die')". ${ }^{57}$ Confucians also highlight the extraordinary significance that their ethical or belief system played in their behavioral

\footnotetext{
I52 Rashiduddin I998, pp. 235-36; Juvaini I997, pp. 79-8I.

I53 Durkheim I986, p. 48.

I54 Hope 20I6, pp. I-2.

I55 Perhaps Mongolian ja'arin (SHM §I2I, 206).

I56 Dawson I955, pp. I4-I5, I95; Jackson and Morgan, I990, pp. 236-37.

I57 Rachewiltz 2007, p. I 20.
} 
patterns. While the Song envoy Zhao Hong reported that "Every undertaking must be in the name of Heaven" among the Mongols, Peng Daya tells us that "With regard to things that they wish to carry out, they say, "Heaven has caused it to be so". "As for things that have already been done by other men, they say "Heaven knows it”. "There is not a single thing which they do not attribute to Heaven. From the Mongol ruler down to his people, there is none who is not so". ${ }^{158}$

Surely, tenggeri, that is, heaven or God, is omnipresent in the SHM and other extant Mongol sources and many have studied the role of tenggeri in Mongol imperial ideology, mostly treating it as a Shamanic deity. However, there have been very few attempts to go beyond tenggeri and to look at the ethical system of the Mongols that made them "have an upright heart" and live in peace and harmony as Carpini admired. ${ }^{159}$ The ideas of "the favor of heaven" (tenggeri-yin ihe'el), törü, khan (qan or qa'an), and the numerical divisional system including the decimal system all predate the Chinggisid rise and are actually recurring elements of pre-modern Inner Asian statecraft and political culture. Most of these institutions were already in place in the time of the Xiongnu, the earliest known Inner Asian Empire. ${ }^{160}$ Xiongnu "chengli" is clearly a Chinese corruption of Inner Asian tengri or tenggeri, and Xiongnu chanyu is an equivalent of later qan or qa'an as heavenly mandated ruler. ${ }^{16 \mathrm{I}}$ Hereditary decimal divisions, the appanage system, the left and right divisions of offices, and the council of ministers and divisional commanders all were elements of Xiongnu statecraft. ${ }^{162}$ Tängri, törü, and qayan all are attested in the Orkhon inscriptions and in Kitan. ${ }^{163}$ While many scholars, such as Golden and Di Cosmo, emphasize the continuity of the Inner Asian imperial political traditions including the decimal system, Hansgerd Cöckenjan documented the continuous use of the decimal system by the Xiongnu, Hsien-pei, Türük, Kitan, Jin and Mongol and Timurid empires. ${ }^{164}$ Lately, Atwood, using recent works on Kitan and other eastern Inner Asian languages, highlights the long-standing state and imperial traditions shared by early medieval Inner Asian states such as the Türk, Kitan and Mongol by philologically reconstructing several enduring institutions associated with imperial family and the comitatus or war band. ${ }^{165}$ Törü was one of these enduring institutions of political culture and, indeed, according to Mahmūd al-Kāšjarī already in the eleventh century, there was a saying "Realm vanishes; törü stays" (êl qaldi törü qalmâs). ${ }^{166}$ This is the political culture from which the Chinggisid state rose.

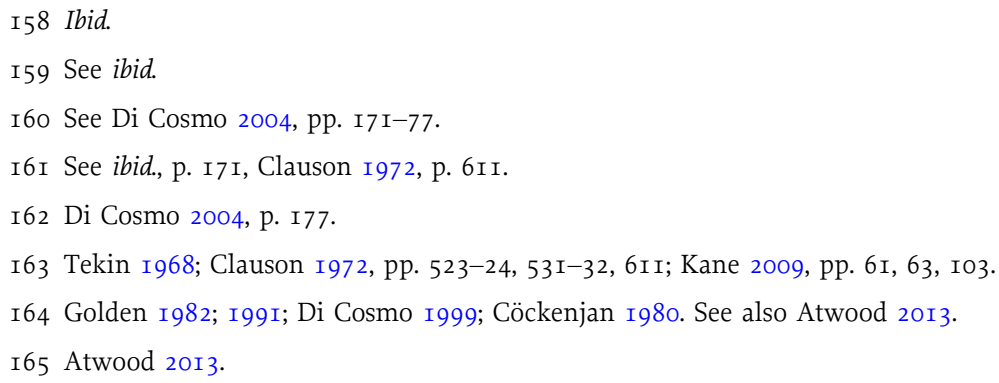

I66 Mahmūd al-Kâšyari I982, p. 276. Robert Dankoff translates this as "The realm has been left behind, but custom cannot be left behind" (Mahmūd al-Kâšyari i982, p. 399). Vadim Trepavlov translates it as "State disappears [but] törü is preserved" (Ischezaet gosudarstvo, [no] sohranyaetsya törü) (Trepavlov I993, p. 4I). 


\section{THE AFTERMATH}

The political structure and culture that gave birth to the Mongol ulus endured beyond I 206 to fundamentally shape the Mongol Empire. The idea of the bounded, limited ulus not only shaped the Mongol ulus but also fundamentally structured the Mongol Empire. The medieval Mongolian ulus was a community of government and as such it denied the status and designation of ulus to those it conquered. Every incorporated polity was uniformly designated as irgen. ${ }^{167}$ Thus, both those integrated to form the Mongol ulus and those incorporated to the Mongol Empire were reduced to irgen or subject peoplehood, making the Mongol Empire a state that encompassed numerous irgens.

However, the Mongol ulus as the Mongol people (mongqol irgen) and, perhaps, as Mongol territory (nuntuq), was not as expansive as the Chinggisid state was. Recounting Chinggis Khan's I206 naming of the noyads (lords) of the Mongol ulus, SHM §202 sums up the event saying, "Besides the Forest People (hoi-yin irgen-ece anggida), the noyad of the Mongol ulus named by Chinggis Khan had been ninety-five". The assumption is that the "Forest People" - who were actually incorporated into the Chinggisid state around I 2 I 7 - were yet to be integrated, and with their integration the Mongol ulus would be complete. The "Forest People" was the boundary - the territorial, demographic, and most importantly, the mental or pre-conceived limit - of the "felt-tent ulus" or "Mongolic ulus" and the Mongol ulus. ${ }^{168}$ Hence the author of the SHM closed the boundary of the Mongol ulus-community at the "Forest People", while the Chinggisid state was ever expanding, conquering new territories and peoples.

Yet, the Mongol ulus as a state was expandable. In fact, because of the question of dynastic succession and the inheritance rights of the princes, Chinggis Khan decided to separate (salqaya) his senior sons allocating them separate domains (ulus) "by expanding [our] nuntuq" (nuntuq a'utkin), and making them "govern aliens" (qari daru'ulun), and the ensuing conquests transformed the Chinggisid ulus-state into an empire (SHM §255). With the conquest of "aliens" (qari) and the "expansion of territory", ulus as a state expanded to encompass the conquered peoples and territories. Thus, the Mongol ulus-state transformed into Yeke Ulus, that is, the Great State, adopting the designation of Yeke Mongqol Ulus, that is, the Great Mongol State meaning Mongolian Great State, the Mongol Empire. ${ }^{\text {I69 }}$ While "expanding [our] nuntuq" again presupposes the boundedness of the nuntuq, "to govern aliens" presupposes the expansion of the nuntuq at the expense of alien territories to conquer "the immense Mother Earth" (ötögen eke a'ui). Consequently, Jochi and Cha'adai were made to rule the conquered "alien" territories furthest from Mongolia. ${ }^{170}$

Chinggis Khan's solution of his succession and the inheritance rights of his senior sons was to shape the Mongol Empire fundamentally, as it entitled and indeed institutionalized their respective domains as separate autonomous domains. By the time of Ögedei's reign, the new imperial framework had already replaced the initial I 206 arrangement, and the

\footnotetext{
I67 Munkh-Erdene 20II.

I68 Munkh-Erdene 20II, p. 2 I7.

I69 Munkh-Erdene 20II, pp. 222-25.

I70 See Juvaini I997, pp. 42-43.
} 
Mongol Empire comprised the "core/main ulus" (qol-un ulus), the imperial metropolis, and the other princely domains (uluses), the heads of which were clearly distinguished as the "princes in charge of the ulus" in contrast to "princes not in charge of the ulus". The "core/main ulus" was nothing other than the Mongol ulus or Mongolia, which subsequently was reduced to a province under Qubilai, who moved the political center away from Mongolia, which eventually transformed the Mongol ulus-people into the "people of the state" (國人 kuo-jên / guoren), a privileged yet uprooted category. ${ }^{\text {I7I }}$ Thus, the idea of the bounded, limited ulus that pre-dated the Chinggisid state left its mark on the Empire's structure too.

Though Peter Jackson downplays Chinggis Khan's initial decision to separate his senior sons by allocating them separate domains, it was precisely this framework that eventually gave rise to the Chinggisid four khanates with some Toluid modifications. ${ }^{172}$ Chinggis Khan's initial arrangement and the resulting four khanates, in their turn, eventually transformed the Mongol Empire into a sort of dynastic "federation". In this sense, Jackson's influential "The Dissolution of the Mongol Empire" was not so much a dissolution as a stage in the transformation of the Mongol Empire. ${ }^{73}$ This does not mean that Chinggis Khan wanted Jochi and Cha'adai to become independent rulers in themselves, hence fragmenting his empire into four khanates. Instead, according to the SHM §255, when both Jochi and Cha'dai nominated Ögedei as successor and pledged to serve him, Chinggis Khan sternly warned his senior sons, saying, "Jochi and Cha'adai, you two keep your word! Don't be laughed at by subjects! Don't be ridiculed by commoners! Once Altan and Quchar pledged their word like this, when they failed to keep their word, how were they dealt with? What was made out of them? Now, I shall separate some of the offspring of Altan and Quchar with you; seeing them how can you fail?" ${ }^{74}$ Neither Jochi nor Cha'adai failed in their word. Moreover, it appears that none of the heads of the regional khanates seems ever to have made an attempt on the throne of the Great Khan, not even the rebellious Qaidu. ${ }^{175}$ Furthermore, none of the khanates ever styled their respective domains as fully independent states by adopting new dynastic or state designations; instead they remained as Jochi's ulus, Chaghatai's ulus, Ögödei's ulus or Batu's ulus, and Orda's ulus. ${ }^{176}$ Meantime, the name of the Chinggisid state remained the Yeke Mongqol Ulus up until the very end of the Empire. ${ }^{177}$

Extant Mongolian decrees and letters from the Chinggisid rulers reveal an important pattern that supports this argument. All the decrees and letters of the qayans (Great

\footnotetext{
I7I Munkh-Erdene 20II, p. 224.

I72 See Jackson I999, p. 5.

I73 Jackson 1978 .

I74 “joci ca'adai qoyar üges-tür-iyen gürülcetkün irgen-e bü ine'e'ülütkün haran-a bu habqari'ulutqun erte altan qucar qoyar ene metü üge baralduju jici üge-tür-iyen ülü gürgü-yin tula ker kikdelü'ei yambar bolqaqdalu'ai edö'e altan qucar qoyar-un uru'ud-aca tan-lu'a salqalduya teden-i üjejü ya'u osoldaqun ta" (SHM §255).

I75 Biran I997.

I76 See Rashiduddin I999.

I77 Munkh-Erdene 20II; Kim 2015.
} 
Khans) uniformly use their respective names followed by the title of qayan and jarliq (decree), that is, "qayan's decree". ${ }^{178}$ However, this is not the case with the rulers of the khanates of Jochi, Cha'adai and Ilkhanate. Except for Öljeitü, who used the title of sultan in his I 305 letter to Philippe IV, King of France, and Abu-Said, who used the title of bayatur qan, none ever used a title, only their names. ${ }^{179}$ Moreover, except for the Jochid khans such as Toqto'a, Özbeg, Keldi Beg, and Abdulla, none used jarliq. ${ }^{\text {I80 }}$ Instead all used üge (word). The Chaghatayd Khans such as Kebek, Tughlugh-Temür, and Iliyās Khwāja all used their names and üge. ${ }^{\text {I8I }}$ Ilkhans such as Abagha, Arghun, Öljeitü, Ghazan, and Abu-Sa'id all used $\ddot{\text { uge. }}{ }^{182}$ However, their subordinates referred to them as qan (not qayan) and their decrees as jrlq or jarliq. ${ }^{183}$ The rulers of the regional khanates addressed the Great Khan as qaran. ${ }^{184}$ Sometime around Güyüg, who used the title of dalai-i:n qan or "khan of the ocean" or the empire, or with the accession of Möngke, the Mongol Great Khans settled on the greater title of qayan while the rulers of the khanates used the lesser title of qan. Moreover, decrees uniformly start with the same formula, "By the power of Eternal Heaven, by the blessing of the Great Fortune” (möngke tengri-i:n kücün-dür yeke suu jali-i:n igege:ndür), while regional rulers such as Ilkhan Arghun and other lesser lords used "by the fortune of the Qayan" (qayan-u suu-dur) in place of "by the blessing of the Great Fortune". The use of Mongolian, and the uniformity of the decree preamble, and the name of the empire and the names of the khanates, the greater and lesser titles, and their correspondences to jarliq and üge not only clearly show the hierarchy of whole and parts, and super and sub-ordination, but also demonstrate the uniformity of the political culture.

Furthermore, non-Chinggisid commanders were generically designated as noyon (or emir), and the noyads or emirs (except Qamar al-Dīn in 1365 in the Chaghatay Khanate, and Esen in 1454 in Mongolia, and Galdan of the Junghars in 1678) rarely made an attempt to style themselves as khan even after the regional khanates had been long in decline and even if they were the effective rulers in their respective domains. ${ }^{185}$ In fact, the so-called "Chinggisid principle" or "the charismatic authority of the Chinggisids" was not so much the result of a personal gift; rather, it was a deeply entrenched dynastic prerogative, a part of the Chinggisid or Inner Asian political culture. ${ }^{186}$

It is true that the institution of the share $(q u b i)$, a Chinggisid solution of princely inheritance rights, further transformed the Empire. The inheritance rights of the evermultiplying Chinggisid princes led to further distribution and allocations of subjects

\footnotetext{
I78 Tumurtogoo 20I0, pp. 9-96.

I79 Tumurtogoo 2006, pp. I56, I85.

I80 Ibid., pp. 280-8I.

I8I Ibid., pp. I63-69.

I 82 Ibid., pp. I 50-56, I84-88. The founder of the Jalayirid dynasty, Sheikh Uwais used üge in his I358 Mongolian decree and used a title of bayatur qan, however he refers his üge as jrlq in the same decree (Tumurtogoo 2006, p. I89).

I83 Tumurtogoo 2006, pp. I62, I63, I65.

I84 Ibid., pp. 33, I52.

I85 Kim I999.

I86 Miyawaki I999, pp. 3I9-3I.
} 
(irgen) and territories (nuntuq) of the Empire as shares (qubi), thus proliferating the princely appanages. It invariably tended to transform the Empire into a collection of petty princely appanages, hence diminishing the power and authority of the Great Khan. Though the centralization efforts on the part of the Great Khans succeeded at times to varying degrees in consolidating the Empire, the heads of the major branches of the dynasty also tried to consolidate their respective domains. In fact, like any of the pre-modern patrimonial-dynastic states, the Chinggisid dynasty was beset by the problem of dynastic succession and princely inheritance, both of which involved questions of sovereignty and legitimacy. However, what differentiates the Chinggisid dynasty from pre-modern sedentary patrimonial dynasties is that it divided its nomadic population into numerous hereditary divisional units ruled by hereditary houses of the noyads or emirs.

Yet, precisely in its "tribesome" and troublesome parts, in the Mongol Empire, where its nomadic population was entirely organized into hereditary divisional units, the rule of the Chinggisids and the Chinggisid power structure lasted the longest. Why? Was it because of the personal charisma of the Chinggisids and the personal bond and loyalty between rulers and followers as the conventional scholarship tends to emphasize? Or was it because of what I call the hereditary divisional system and what Atwood calls "appanage communities"? I would argue for the latter, simply because of the fact that those who were born and raised under the Chinggisid hereditary decimal divisions and the draconian legal regulations imposed upon them had no choice but to serve their commander or ruler loyally and obediently. ${ }^{\mathrm{I} 87}$ In fact, the hereditary decimal divisions were the bedrock of the Chinggisid state and, for that matter, any of the Eurasian nomadic states that employed the numerical divisional system. The military-oriented, hierarchically-nested numerical divisional system and its command structure armed Inner Asian state-builders with a superb "synoptic view" or "seeing like a state vision", furnishing them with the necessary "legibility" and "governmentality", thus solving for them what Michel Foucault calls "the problematic of government" or what James Scott calls the "central problem in statecraft". ${ }^{88}$ In this understanding, then, if both Foucault and Scott are correct in their treatments of pre-modern sedentary states, the Inner Asian states enjoyed superb legibility and governmentality as compared with their sedentary neighbors.

However, these very divisions and their lordly reincarnations have long been viewed as tribes and clans, and consequently Inner Asian politics has long been defined as fluid, fractious, and unstable, determined and defined by swarming tribes and clans as if it were lacking any enduring social, political institutions and order. However, the fluidity that the authors note is, then, not because Inner Asian nomads were organized into bottom-up fractious conical clans but because it was organized into top-down administrative divisions that could be divided and re-divided or re-grouped at any given time if the ruler had sufficient power and the need to do so.

Most importantly, with the expansion of the Chinggisid state, törü, yosu, jasaq and jarliq and jarqu expanded to rule the whole of Eurasia as Mongolian or Chinggisid törü, yosu, jasaq, jarliq and jarqu. Thus, Ilkhan Arghun unequivocally declared to Pope Nicholas IV

I87 See Hsiao I978, pp. 72-87.

I88 See Foucault I994; Scott I998. 
in I 290 that "[We], the descendants of Chinggis Khan are in accordance with our own Mongolian töre". ${ }^{89}$ In fact, while in the eastern half of the Mongol empire the ideas of törü, yosu, jasaq, jarliq and jarqu have remained central to any state-building or statecraft down to the present day, Mongolian or Chinggisid törä, yosun, yasaq (or yasa), yarliq and yarqhu remained as potent sources of state-building, statecraft and socio-political order for the Timurids, the Ottomans and the Mughals up until the early sixteenth century at the least. ${ }^{190}$ Temür "staunchly adhered to" Chinggisid törä and yosun "over the Islamic Sharī'a”, and törä remained "a kind of unwritten 'constitution"” in his realm. ${ }^{\mathrm{IgI}}$ In fact, as Maria Subtelny's (2007, pp. I5-42) own rich documentation of Timuro-Chinggisid törä, yosun and yasaq show, Temür, a "great commander" (amir kabir) and "son-in-law" (kürägän), who repeatedly enthroned Chinggisid Khans and remained true to Chinggisid törä, yosun and yasaq, appears to have built his political authority within the confines of the Chinggisid törä, yosun and yasaq. ${ }^{192}$

Indeed, Zahīr al-Dīn Muhammad Babur, a Timuro-Chinggisid prince and founder of the Great Mughal Empire, and "a keen observer of Timurid and Mongol traditions", left a penetrating observation on törä that captures the essence and the nature of törü. ${ }^{193} \mathrm{He}$ wrote that "In former times our fathers and forefathers meticulously observed the Genghisid Code (Cinggiz törä). In assemblies and at court, at feasts and dinners, in seating and serving, they did nothing counter to the code (törä). However, Genghis Khan's code (Cinggiz Xānnïng törä) is not a binding text according to which a person must act absolutely. One must act in accordance with a good rule when someone leaves one behind; if, however, an ancestor has done a bad thing, it should be replaced by a good one. ${ }^{194}$ Indeed, törü has never been a categorical or binding text; but it has always been a good rule; and it has always been an all-embracing moral code and good custom, especially in statecraft and political authority. To invoke Edward Thompson, törü was (and still is) a person's second nature, as "Custom was man's 'second nature", and the wheels of törü or tyranny of törü, as rules, and precedents, which in some circumstances were codified and enforced in law, was the culture and the common law of the pre-modern Eurasian socio-political order. ${ }^{\mathrm{I} 95}$

I89 “Chinggis qan-u uruqud öber-ün mongqoljin töreber aju”. Previously, töreber has been mistakenly read as durabar and identified with dura as à sa guise, à volonté, that is will or volition, and has consequently been misconstrued as "de plein grê", that is, voluntarily or willingly (Mostaert and Cleaves I952, pp. 450-5I, 463). However, a grapheme o (gedesü or belly) that has been read as $u$ has i (silbi or shin bone), though somewhat unnoticeable to the naked eye. Thus, it is not o or $u$ but oi or $\ddot{o}$, hence töre. Obviously, the mistake seems to have been caused by Mongolian vowel harmony, because after $r$ appears e (acuq or tooth) which can be read either as $a$ or $e$ depending on whether the preceding vowel is masculine or feminine, and in this case, it has been read as $a$, for Mostaert and Cleaves took the preceding vowel as $u$, hence dura. On the other hand, törü is the established writing of the word in classical Mongolian. However, while in the SHM törü appears as töre, törö, and dörö, in Timurid sources it often appears as törä, that is, töre. Note that all the Mongolian graphemes here are in horizontal positions. Rotate clockwise 90 degrees.

I90 Subtelny 2007; Burak 20I5, pp. 2I4-23.

I9I Subtelny 2007, pp. I7-I8.

I92 Subtelny 2007, pp. I5-42; Thackston I989, pp. I-2.

I93 Subtelny 2007, p. I7.

I94 Thackston I989, pp. 7-8. See Stephen Dale (Dale 2004, p. I7I); and Subtelny 2007, pp. I7-I8 for slightly different translations of the passage.

I95 Thompson I993, pp. I-I5. Thompson uses Francis Bacon's expressions such as "wheeles of custome”, and 
However, the conventional scholarship not only assigns pre-modern Inner Asian politics almost always to the irrational, personal, charismatic and impermanent side of the Weberian dichotomies but also by emphasizing the personal charisma of the statebuilders virtually neglects enduring political traditions of pre-modern Inner Asian political culture. The Weberian view is "Charismatic domination means a rejection of all ties to any external order ... Hence, its attitude is revolutionary and transvalues everything; it makes a sovereign break with all traditional or rational norms". "Genuine charisma is absolutely opposed to the structure of domination. It does not appeal to an enacted or traditional order nor does it base its claims upon acquired rights". "Charismatic rule is not managed according to general norms, either traditional or rational ... It is 'revolutionary' in the sense of not being bound to the existing order. ${ }^{196}$ However, both Temüjin and Temür, who have conventionally been depicted as the epitome of charismatic "nomadic warlord", did not reject the existing socio-political order, did not break with all the traditional or rational norms, and did not oppose the structure of domination. On the contrary, they appealed to the enacted or traditional order, based their claims upon their acquired rights, and pursued their policies in accordance with the general norms, either traditional or rational. Their legitimizations fall into a mixture of what Weber called "traditional" and "legal" types rather than "charismatic". ${ }^{197}$ In fact, it is questionable if any political authority was ever built on what Max Weber calls "pure" or "genuine" personal charisma. ${ }^{198}$

It is hoped that the story, the place, and the culture presented here will show that premodern Mongolian and Inner Asian politics were neither fluid nor pragmatic. Instead, in addition to its hereditary divisional system, it was guided by the idea of törü, which appears very similar to the Indian or Buddhist idea of dharma, the Chinese idea of dao, and the European idea of natural law. Indeed, the oral messages that Temüjin is said to have sent to Ong Khan were in fact a declaration of his legitimate grievances, his demanding of war reparations, and his declaration of war, just as Nurhachi did in his "Seven Great Grievances” against the Ming in I6I8, though Temüjin's declaration appears much more sophisticated than that of Nurhachi. ${ }^{199}$

In fact, 430 years after Temüjin's enthronement in I206, the Manchu ruler Hong Taiji was enthroned in I636 as a successor to the Mongol Great Khan, again with "the favor of Heaven" and again as a ruler who "always upholds the great törü". ${ }^{200}$ Ligdan, the last Chinggisid Great Khan, was blamed for breaking "the unbreakable törü” (ebdereshi ügei

“Tyranny which Custom usurps over us”; Thompson I993, pp. 2-3. Franz Boas similarly talked about breaking "the shackles of dogma" or "the shackles that tradition has laid upon us"; Krupat I998, p. I02. In fact, "breaking the shackles of tradition" seems to have been a recurring discourse since the Enlightenment and the famous "invention of tradition" can be considered as a part of this discussion; Hobsbawm and Ranger I983.

I96 Weber I946, pp. 250, 262, 296.

I97 Ibid., p. 79.

I98 Ibid., pp. 245-64.

I99 Crossley I999, pp. I35-76.

200 DUMH, p. 802. For instance, Hong Taiji’s enthronement pledge to Heaven and Earth uses "tengri öröshiyejü or tengri-yin tagalal" (blessed by Heaven or by the favor of Heaven) as well as "yeke törü-yin tula ürgüljide setgijü" (always thinking for the great törü). 
törü) hence losing "the favor of Heaven”. ${ }^{201}$ Furthermore, Hong Taiji strengthened his claim for the imperial throne with the supposed Jade Seal (has erdeni-yin tamga) of the Mongol Great Khans and a golden statue of the Mahākāla Buddha, object of a supposed cult of the Mongol Great Khans. ${ }^{202}$ Reputedly, Hong Taiji even made Erhe Hongqor Ejei, a son of Ligdan Khan and the heir apparent, enthrone him. ${ }^{203}$ Thus Ligdan, the last Chinggisid Great Khan, was to repeat the unfortunate destiny of Ong Khan while Erhe Hongqor Ejei, a minor, was to hand the Chinggisid sovereignty over to Hong Taiji. Yet, 275 years later, the Mongols declared "the establishment a new törü" because "the Manchu törü was broken" due to "the law of Heaven" (tenggeri-yin yosu), and enthroned Jibzundamba Khutugtu as "the reincarnation of the sons of Tüshiyetü Khan, a seed of the seed of the ancient Great Chinggis Khan of our Mongol ulus". ${ }^{204}$ The Mongols rationalized, "There is no eternity in the decree of Heaven (tenggeri-yin boshgo), only those who possess the wisdom (erdem) can receive it”. ${ }^{205}$ Soon Mongolia's törü lost heaven (tenggeri) as its source of legitimacy; instead arad or the people replaced it, hence it was transformed into arad-un törü, that is, the people's törü. Yet, törü still governs as norm, principle, custom, manner, law, government, and the state. Obviously, its source of legitimacy is no longer the "Mandate of Heaven" or "Grace of God" but the people as the sovereign. Yet törü remains as a given, human and natural.

\title{
REFERENCES
}

\begin{abstract}
Abbreviations
DUMH: Dayiching ulus-un magad hauli (Veritable Records of the Qing Dynasty). Hoyadugar emhitgel (Second Volume), Tayizung-un magad hauli (Veritable Records of Taizong). Öbür mongqol-un soyol-un heblel-ün horiy-a (Inner Mongolian Cultural Printing House), I990.

SHM: The Secret History of the Mongols. Consulted in the following editions, concordances, and translations: Index to the Secret History of the Mongols, Igor de Rachewiltz. Bloomington: Indiana University Press, I972.

The Secret History of the Mongols, Volume I, trans. and ed. Francis Woodman Cleaves. Cambridge, MA: Harvard University Press, I982.

The Secret History of the Mongols: The Life and Times of Chinggis Khan, trans. and ed. Urgunge Onon. London: Routledge Curzon, 200I.

The Secret History of the Mongols: A Mongolian Epic Chronicle of the Thirteenth Century, 2 vols. with continuous pagination, trans. and ed. Igor de Rachewiltz. Leiden: E.J. Brill, 2006.
\end{abstract}

\section{Secondary sources}

Amitai and and Biran 20I5

Amitai, Reuven, and Michal Biran, eds. Nomads as Agents of Cultural Change: The Mongols and Their Eurasian Predecessors. Honolulu: University of Hawai'i Press, 2015.

Atwood 20I5

Atwood, Christopher. “The Administrative Origins of Mongolia’s 'Tribal' Vocabulary.” Eurasia: Statum et Legem (Euraziya: Gosudarstvo i Pravo) I:4 (2015), pp. 7-45.

$20 \mathrm{I}$ DUMH, p. 744; Li and Nyamka 2004, p. 28. Sholoi, the Setsen Khan of Khalkha, wrote in his I635 letter to Hong Taiji that "Khutugtu Khan (Ligdan) broke the unbreakable törü" (Evdershgüi töriig evdev Khutugt Khaan) (Li and Nyamka 2004, p. 28). See DUMH, p. 744 for a slightly different version of the letter.

202 DUMH, pp. 622-95, 70I-I7; See also Okada I99I for the jade seal; Crossley I999 for the Mahākāla.

203 DUMH, p. 804; see also Okada I991, p. I72.

204 Magsarjav I994, p. I2; Ochir and Purvee I982, p. III.

205 Magsarjav 1994, p. I5. 
Atwood 2013

Atwood, Christopher. "Some Early Inner Asian Terms Related to the Imperial Family and the Comitatus." Central Asiatic Journal 56 (2013), pp. 49-86.

Atwood 2012

Atwood, Christopher. "Banner, Otog, Thousand: Appanage Communities as the Basic Unit of Traditional Mongolian Society.” Mongolian Studies 32 (20I2), pp. I-76.

Atwood 2010a

Atwood, Christopher. "The Notion of Tribe in Medieval China, Ouyang Xiu and the Shatuo Dynastic Myth.” In Miscellanea Asiatica: Mélandes en l'honneur de Françoise Aubin, ed. Denise Aigle, Isabelle Charleux, Vincent Gossaert and Roberte Hamayan, pp. 593-62I. Sankt Augustin, Germany: Institut Monumenta Serica, 2010.

Atwood 20Iob

Atwood, Christopher. "How the Mongols Got a Word for Tribe-and What It Means." Studia Historica Mongolica (Menggu shi yanjiu) Io (2010), pp. 63-89.

Atwood 2006

Atwood, Christopher. "Titles, Appanages, Marriages, and Officials: A Comparison of Political Forms in the Zünghar and Thirteenth-Century Mongol Empires." In Imperial Statecraft: Political Forms and Techniques of Governance in Inner Asia, 6th-2oth Centuries, ed. David Sneath, pp. 207-43. Washington: Western Washington University, Center for East Asian Studies. 2006.

Atwood 2004

Atwood, Christopher. Encyclopedia of Mongolia and the Mongol Empire. New York: Facts on File, Inc., 2004.

Barfield I989

Barfield, Thomas. The Perilous Frontier: Nomadic Empires and China, 22 I BC to AD I757. Cambridge, MA: Blackwell, I989.

Biran 20I5

Biran, Michal. "The Mongols and Nomadic Identity: The Case of the Kitans in China." In Nomads as Agents of Cultural Change: The Mongols and Their Eurasian Predecessors, ed. Reuven Amitai and Michal Biran, pp. I52-8I. Honolulu: University of Hawai'i Press, 2015.

Biran 2005

Biran, Michal. The Empire of the Qara Khitai in Eurasian History: Between China and the Islamic World. Cambridge: Cambridge University Press, 2005.

Biran I997

Biran, Michal. Qaidu and the Rise of the Independent Mongol State in Central Asia. Richmond: Curzon, I997.

Bisson 2009

Bisson, Thomas. 2009. The Crisis of the Twelfth Century: Power, Lordship, and the Origins of European Government. Princeton: Princeton University Press, 2009.

Burak 2015

Burak, Guy. The Second Formation of Islamic Law: The Hanafi School in the Early Modern Ottoman Empire. Cambridge: Cambridge University Press, 2015.

Clauson I972

Clauson, Gerard. An Etymological Dictionary of Pre-Thirteenth-Century Turkish. Oxford: Clarendon Press. I972.

Cleaves 200I

Cleaves, Francis. An Early Mongolian Version of the Hsiao ching (The Book of Filial Piety). Chapters Seven, Eight, and Nine. Transcription, Translation, Commentary. Chapters Ten through Seventeen. Transcription, Translation. Bloomington, IN: Publications of the Mongolia Society, Occasional Papers 23, $200 \mathrm{I}$.

Cleaves I992

Cleaves, Francis. "The Fourth Chapter of an Early Mongolian version of the 'Hsiao Ching', Mongolian Studies I5, The Nicholas Poppe Memorial Issue (I992), pp. I37-50.

Cleaves I99I

Cleaves, Francis. "The Third Chapter of an Early Mongolian version of the 'Hsiao Ching,." Mongolian Studies I4, The Hangin Memorial Issue (I99I), pp. I I7-43.

Cleaves I982

Cleaves, Francis. "The First Chapter of an Early Mongolian version of the 'Hsiao Ching," Acta Orientalia Academiae Scientiarum Hungaricae 36:1/3 (I982), pp. 69-88. 
Cleaves and Rachewiltz 2007

Cleaves, Francis. "An Early Version of the 'Hsiao Ching': 3. Chapters Fourteen to Seventeen." Acta Orientalia Academiae Scientiarum Hungaricae 60:2 (2007) pp. I45-60.

Cleaves and Rachewiltz 2006

Cleaves, Francis. "An Early Version of the 'Hsiao Ching': 2. Chapters Ten to Thirteen." Acta Orientalia Academiae Scientiarum Hungaricae 59:4 (2006) pp. 393-406.

Cöckenjan I980

Cöckenjan, Hans. "Zur Stammesstruktur und Heeresorganisation Altaischer Völker Das Dezimalsystem." In Europa Slavica - Europa Orientalis: Festschrift für Herbert Ludat zum 70. Geburtstag, ed. Klaus-Detlev Grothusen and Klaus Zernack, pp. 5I-86. Berlin: Duncker \& Humblot, 1980.

Crossley I999

Crossley, Pamela. A Translucent Mirror: History and Identity in Qing Imperial Ideology. Berkeley and Los Angeles: University of California Press, 1999.

Dale 2004

Dale, Stephen. The Garden of the Eight Paradises: Babur and the Culture of Empire in Central Asia, Afghanistan and India (I483-I530). Leiden and Boston: Brill, 2004.

Dawson 1955

Dawson, Christopher, ed. The Mongol Mission: Narratives and Letters of the Franciscan Missionaries in Mongolia and China in the Thirteenth and Fourteenth Centuries. New York: Sheed and Ward, 1955.

Di Cosmo 2004

Di Cosmo, Nicola. Ancient China and Its Enemies: The Rise of Nomadic Power in East Asian History. Cambridge: Cambridge University Press, 2004.

Di Cosmo I 999

Di Cosmo, Nicola. "State Formation and Periodization in Inner Asian History." Journal of World History Io (I999), pp I-40.

Di Cosmo, Frank and Golden 2009

Di Cosmo, Nicola, Allen J. Frank and Peter B. Golden, eds. The Cambridge History of Inner Asia: The Chinggisid Age. Cambridge: Cambridge University Press, 2009.

Durkheim I986

Durkheim, Emile, "The Concept of the State." In Durkheim on Politics and the State, ed. Anthony Giddens, trans. W. D. Halls, pp. 32-72. Cambridge: Polity Press, 1986.

Foucault 1994

Foucault, Michel. "Governmentality." In Power: The Essential Works of Michel Foucault 1954-1984. Vol. 3. ed. James D. Faubion, trans. Robert Hurley et al., pp. 20I-22. London: Penguin, I994.

Golden 2009

Golden, Peter. "Migrations, Ethnogenesis." In The Cambridge History of Inner Asia: The Chinggisid Age, ed. Nicola Di Cosmo, Allen J. Frank and Peter B. Golden, pp. I09-19. Cambridge: Cambridge University Press, 2009.

Golden I99I

Golden, Peter. "Nomads and Their Sedentary Neighbors in Pre-Cinggisid Eurasia." Archivum Eurasiae Medii Aevi 7 (I99I), pp. 43-44.

Golden I 982

Golden, Peter. "Imperial Ideology and the Sources of Political Unity amongst the Pre-Chinggisid Nomads of Western Eurasia." Archivum Eurasiae Medii Aevi 2 (1982), pp. 37-77.

Hobsbawm and Ranger 1983

Hobsbawm, Eric, and Terence Ranger. The Invention of Tradition. Cambridge: Cambridge University Press, I983.

Hodous 2012/2013

Hodous, Florence. "The Quriltai as a Legal Institution in the Mongol Empire." Central Asiatic Journal 56 (2012/ 2013), pp. 87-102.

Hope 2016

Hope, Michael. Power, Politics and Tradition in the Mongol Empire and the Ilkhanate of Iran. Oxford: Oxford University Press, 2016.

Hsiao 1978

Hsiao, Ch'i-ch'ing. The Military Establishment of the Yuan Dynasty. Cambridge, MA: Harvard University Press, I978. 
Humphrey and Hürelbaatar 2006

Humphrey, Caroline, and A. Hürelbaatar. "The Term törü in Mongolian History.” In Imperial Statecraft: Political Forms and Techniques of Governance in Inner Asia, 6th-2oth Centuries, ed. David Sneath. Bellingham: Western Washington Press, pp. 263-92.

Hunter 1989 Hunter, Erica. "The Conversion of the Kerait to Christianity in A.D. I007." Zentralasiatische Studien 22 (1989), pp. I42-I63.

Iakinf $\mathrm{I} 828$

Iakinf. Zapiski o Mongolii, Volume I, 2. SanktPeterburg': v’ Tipografii Karla Kraiya, I828.

Jackson I999 Jackson, Peter. "From Ulus to Khanate: The Making of the Mongol States, c. I220-c. I 290." In The Mongol Empire and Its Legacy, ed. Reuven Amitai-Preiss and David O. Morgan, pp. I2-38. Leiden: Brill, I999.

Jackson 1978

Jackson, Peter. "The Dissolution of the Mongol Empire." Central Asiatic Journal, 22:3/4 (1978), pp. I86-244.

Jackson and Morgan I990

Jackson, Peter, and David Morgan, trans. and eds. The Mission of Friar William of Rubruck: His Journey to the Court of the Great Khan Möngke I253-I255. London: The Hakluyt Society, I990.

Janhunen 2012

Janhunen, Juha. Mongolian. London Oriental and African Language Library I9. Amsterdam/Philadelphia: John Benjamins Publishing, 2012.

Juvaini 1997

Juvaini. Genghis Khan: The History of the World-conqueror by 'Ala-ad-Din 'Ata-Malik Juvaini. trans. Andrew Boyle. With a new introduction and bibliography by David Morgan. Manchester: Manchester University Press, I997.

Kane 2009

Kane, Daniel. The Kitan Language and Script. Leiden: Brill, 2009.

Kim 2015

Kim, Hodong. “Was ‘Da Yuan' A Chinese Dynasty.” Journal of Song-Yuan Studies 45 (2015), pp. 279-305.

Kim 1999

Kim, Hodong. "The Early History of the Moghul Nomads: The Legacy of the Chaghatai Khanate." In The Mongol Empire \& Its Legacy, ed. Reuven Amitai-Preiss and David O. Morgan, pp. 290-3I8. Leiden: Brill, I999.

Kowalewski 1849

Kowalewski, Joseph. Mongol'sko-Russko-Frantsuzskii slovar', Vol. 3. Kazan': University Press, I849.

Kradin and Skrynnikova 2009

Kradin, Nikolay, and Tatyana Skrynnikova. "Stateless Head: Notes on Revisionism in the Studies of Nomadic

Societies." Ab Imperio 4 (2009), pp. 633-55.

Krupat 1998

Krupat, Arnold. The Turn to the Native: Studies in Criticism and Culture. Lincoln and London: University of Nebraska Press, I998.

Li and Nyamka 2004

Li Bao-wen and Nyamka, eds. XVII zuuny tergüün khagasyn Mongol, Manjiin hariltsaand kholbogdokh barimt bichgüüd. Ulaanbaatar, 2004.

MacIntyre 2007

MacIntyre, Alasdair. After Virtue: A Study in Moral Theory. Third edition. Notre Dame: University of Notre Dame Press, 2007.

Magsarjav 1994

Magsarjav, N. Mongol ulsyn shine tüüh (A New History of Mongolia). Ulaanbaatar, [1927] 1994.

Mahmūd al-Kāšjarī r 982

Mahmūd al-Kāšyarī. Compendium of the Turkic Dialects (Dīwān Luyāt at-Turk). Ed. and trans. Robert Dankoff,

Part I. Harvard University Printing Office, I982.

Miyawaki 1999

Miyawaki, Junko. "The Legitimacy of Khanship among the Oyirad (Kalmyk) Tribes in Relation to the Chinggisid Principle." In The Mongol Empire \& Its Legacy, ed. Reuven Amitai-Preiss and David O. Morgan, pp. 319-3I. Leiden: Brill, I999.

Moisés 20II

Moisés, José. "Civic Culture." In International Encyclopedia of Political Science, ed. Bertrand Badie, Dirk Berg-Schlosser and Leonardo Morlino, Volume I, pp. 243-48. Thousand Oaks: Sage Publications, 20I I. 
Mostaert and Cleaves I952

Mostaert, Antoine, and Francis Woodman Cleaves. "Trois documents mongols des Archives secretes vaticanes." Harvard Journal of Asiatic Studies I5:3-4 (1952), pp. 419-506.

Mote 1999

Mote, Frederik W. Imperial China 900-I800. Cambridge, MA: Harvard University Press, I 999.

Munkh-Erdene 2016

Munkh-Erdene, Lhamsuren. 2016. "Political Order in Pre-Modern Eurasia: Imperial Incorporation and the Hereditary Divisional System." Journal of the Royal Asiatic Society 3:26:4 (2016), pp. 633-55.

Munkh-Erdene 20II

Munkh-Erdene, Lhamsuren. "Where Did the Mongol Empire Come From? Medieval Mongol Ideas of People, State and Empire." Inner Asia I 3:2 (201 I), pp. 2 I I-37.

Munkh-Erdene 2010

Munkh-Erdene, Lhamsuren. "The I640 Great Code: An Inner Asian Parallel to the Treaty of Westphalia." Central Asian Survey 29:3 (2010), pp. 269-88.

Munkh-Erdene 2006

Munkh-Erdene, Lhamsuren. "The Mongolian Nationality Lexicon: From the Chinggisid Lineage to Mongolian Nationality (From the Seventeenth to the Early Twentieth Century)." Inner Asia 8 (2006), pp. 5I-98.

Munkuev I975

Munkuev, Nikolai, trans. Men-da-bei-lu: Polnoe opisanie Mongolo-Tatar. Moskva: Nauka, I975.

Ochir and Purvee 1982

Ochir, A., and G. Purvee, ed. Mongoliin ard tümnii Ig I oni u ndesnii erkh chölöo, tusgaar togtnoliin tölöo temtsel, Barimt bichgiin emkhtgel I900-I9I4 (Mongolian people's I9I I struggle for national liberty and independence, a collection of documents I900-I9I4). Ulaanbaatar: State Printing House, I982.

Oda 2015

Oda, Juten. A Study of the Buddhist Sütra called Säkiz Yükmäk Yaruq or Säkiz Törlügin Yarumiš Yaltrïmiš in Old Turkic. Turnhout: Brepols Publishers, 2015.

Okada I99I

Okada, Hidehiro. "Origin of the Caqar Mongols." Mongolian Studies I4, The Hangin Memorial Issue (I99I), pp. I55-79.

Poppe 1967

Poppe, Nicholas. The Twelve Deeds of Buddha: A Mongolian Version of the lalitavistara Mongolian Text, Notes, and English Translation. Seattle: University of Washington Press, I967.

Qorin nigetü tayilburi toil 1979

Qorin nigetü tayilburi toli (Twenty-one volume dictionary), Öbür mongqol-un arud-un heblel-ün horyi-a (Inner Mongolian Committee of People's Press), I979 [1717].

Rachewiltz 2007

Rachewiltz, I. D. "Heaven, Earth and the Mongols in the Time of Cinggis Qan and His Immediate Successors (ca. II60-I260) - a Preliminary Investigation." Leuven Chinese Studies I7 (2007), pp. I07-44.

Rashiduddin 1998, I999

Rashiduddin Fazlullah. Jami'u't-tawarikh Compendium of Chronicles. A History of the Mongols. Parts I, II trans. Wheeler Thackston. Cambridge, MA: Harvard University. I998, I999.

Ratchnevsky I99I

Ratchnevsky, Paul. Genghis Khan: His Life and Legacy, trans. and ed. Thomas Haining. Oxford: Blackwell, I99r. Reynolds I997

Reynolds, Susan. Kingdoms and Communities in Western Europe, 900-I300. 2nd edition. Oxford: Clarendon Press, I997.

Róna-Tas 2016

Róna-Tas, András. "Remarks on the Ethnonym Khitan." Turkic Languages 20 (2016), pp. 157-69.

Scott 1998

Scott, James. Seeing Like a State: How Certain Schemes to Improve the Human Condition Have Failed. New Haven and London: Yale University Press, I998.

Shagj 1998

Shagj, Mongqol ügen-ü tayilburi toli (Dictionary of Mongolian words). Beijing: Dumdadu ulus-un ündüsütün-ü heblel-ün horyi-a, I998 [1929].

Skrynnikova 2013

Skrynnikova, Tatyana. Kharisma i vlast' v epokhu Chingis-Khana. Sankt-Peterburg: Evraziya, 2013. 
Sneath 2007

Sneath, David. Headless State: Aristocratic Orders, Kinship Society, \& Misrepresentations of Nomadic Inner Asia. New York: Columbia University Press, 2007.

Subtelny 2007

Subtelny, Maria. Timurids in Transition: Turko-Persian Politics and Acculturation in Medieval Iran. Leiden and Boston: Brill, 2007.

Szunyogh I 955

Szunyogh, Bela. Psychological Warfare: An Introduction to Ideological Propaganda and the Techniques of Psychological Warfare. New York: The William-Frederick Press, 1955.

Tekin 1968

Tekin, Talat. A Grammar of Orkhon Turkic. Bloomington, IN: Mouton and Co, I968.

Thackston 1989

Thackston, Wheeler. A Century of Princes: Sources on Timurid History and Art. Cambridge, MA: Aga Khan Program for Islamic Architecture, I989.

Thompson 1993

Thompson, Edward. Customs in Common. London: Penguin Books, I993.

Timkovsky I824

Timkovsky, Egor'. Puteshestvie v' Kitai chrez' Mongoliyu v' I820 I I82 I godah', Volume 3. Sanktpeterburg': V' Tipographii Meditsinskago Departmenta Ministerstva Vnutrennih' Del', I824.

Togan 1998

Togan, Isenbike. Flexibility and Limitation in Steppe Formations: The Kerait Khanate and Chinggis Khan. Leiden: Brill, 1998.

Togan 2015

Togan, Isenbike. "The Use of Sociopolitical Terminology for Nomads: An Excursion into the Term Buluo in Tang China." In Nomads as Agents of Cultural Change: The Mongols and Their Eurasian Predecessors, ed. Reuven Amitai and Michal Biran, pp. 88-117. Honolulu: University of Hawai'i Press, 2015.

Trepavlov 1993

Trepavlov, Vadim. Gosudarstvennyi stroi Mongol'skoi imperii XIII v.: Problema istoricheskoi preemstvennosti. Moskva: Vostochnaya literatura, 1993.

Tumurtogoo 2010

Tumurtogoo, Domi, eds. Mongolian Monuments in 'Phags-pa Script: Introduction, Transliteration, Transcription and Bibliography. Language and Linguistic Monograph Series 42. Taipei: Institute of Linguistics, Academia Sinica, 2010.

Tumurtogoo 2006

Tumurtogoo, Domi, ed. Mongolian Monuments in Uighur-Mongolian Script (XIII-XIV Centuries): Introduction, Transcription and Bibliography. Language and Linguistic Monograph Series A-II, Taipei: Institute of Linguistics, Academia Sinica, 2006.

Twitchett and Tietze I994

Twitchett, Denis, and Klaus-Peter Tietze, "The Liao." In Alien Regimes and Border States 907-I368, The Cambridge History of China Volume 6, ed. Denis Twitchett and John K. Fairbank, pp. 43-I53. Cambridge: Cambridge University Press, I994.

Weber 1946

Weber, Max. From Max Weber: Essays in Sociology, trans. and eds. H. H. Gerth and C. Wright Mills. New York: Oxford University Press, I946.

Wittfogel and Fêng 1949

Wittfogel, Karl, and Fêng Chia-Shêng. History of Chinese Society Liao (907-I I25). Philadelphia: The American Philosophical Society, I949. 